\title{
Proposed minimal standards for describing new genera and species of the suborder Micrococcineae
}

\section{Correspondence \\ P. Schumann psc@dsmz.de}

\author{
Peter Schumann, ${ }^{1}$ Peter Kämpfer, ${ }^{2}$ Hans-Jürgen Busse ${ }^{3}$ and \\ Lyudmila I. Evtushenko ${ }^{4}$ for the Subcommittee on the Taxonomy \\ of the Suborder Micrococcineae of the International Committee on \\ Systematics of Prokaryotes
}

\author{
${ }^{1}$ DSMZ-Deutsche Sammlung von Mikroorganismen und Zellkulturen GmbH, Inhoffenstraße 7B, \\ 38124 Braunschweig, Germany \\ ${ }^{2}$ Institut für Angewandte Mikrobiologie, Justus-Liebig-Universität, 35392 Giessen, Germany \\ ${ }^{3}$ Institut für Bakteriologie, Mykologie und Hygiene, Veterinärmedizinische Universität, A-1210 Wien, \\ Austria \\ ${ }^{4}$ All-Russian Collection of Microorganisms (VKM), G. K. Skryabin Institute of Biochemistry and \\ Physiology of Microorganisms, RAS, Pushchino, Moscow Region 142290, Russia
}

\section{INTRODUCTION}

The suborder Micrococcineae was established by Stackebrandt et al. (1997) on the basis of a characteristic set of $16 \mathrm{~S}$ rRNA gene signature nucleotides. Subsequent reclassifications and descriptions of additional genera have necessitated the dynamic adaptation of the originally proposed sets of signature nucleotides since new members added to the suborder have given a fresh insight into its genotypic diversity (Stackebrandt \& Schumann, 2006; Zhi et al., 2009). Consequently, an emended description of the suborder Micrococcineae was proposed on the basis of a revised set of 16S rRNA gene signatures (Zhi et al., 2009): $127: 234$ (A-U), 598:640 (U-G), 657:749 (U-A), 953:1228 (G-C), 986:1219 (A-U), $987: 1218(\mathrm{~A}-\mathrm{U})$ and 1362 (A). At the time of writing, the suborder comprises 15 recognized families (Stackebrandt et al., 1997; Stackebrandt \& Schumann, 2000b; Li et al., 2005, 2008; Zhi et al., 2009) and 86 genera, including two pairs of genera with names that are heterotypic synonyms (Microbacterium/

Abbreviations: FT-IR, Fourier-transform-infrared spectroscopy; MALDITOF, matrix assisted laser desorption ionization time-of-flight.
Aureobacterium and Rothia/Stomatococcus) and one pair of homotypic synonyms (Pseudoclavibacter/Zimmermannella) (Table 1 and http://www.the-icsp.org/taxa/ micrococcineaelist.htm).

Whereas the suborder Micrococcineae is defined solely by the set of $16 \mathrm{~S}$ rRNA gene signature nucleotides (Stackebrandt et al., 1997; Zhi et al., 2009), the affiliation of its members to genera and species requires a comprehensive investigation of genotypic and phenotypic (including chemotaxonomic) characteristics. The currently recognized organisms of the suborder Micrococcineae share several common phenotypic and genotypic features. Most of them are chemoheterotrophs and strict or facultative aerobes characterized by the oxidative type of metabolism. The cells are Gram-positive in terms of the cell-wall structure and do not form endospores. Although coccoid cells, branching hyphae or cell division by multiseptation are morphological features of some genera, the cells of most members of the suborder are irregular rods in an angular arrangement ('coryneform' morphology). Menaquinones are present in all members (except for the 
Table 1. Families, genera and their type species belonging to the suborder Micrococcineae

\begin{tabular}{|c|c|}
\hline Taxa & Reference \\
\hline Family Beutenbergiaceae Zhi et al. 2009 & Zhi et al. (2009) \\
\hline Genus Beutenbergia Groth et al. 1999 (type genus) & Groth et al. (1999b) \\
\hline Beutenbergia cavernae Groth et al. 1999 (type species) & Groth et al. (1999b) \\
\hline Genus Salana Von Wintzingerode et al. 2001 & von Wintzingerode et al. (2001) \\
\hline Salana multivorans Von Wintzingerode et al. 2001 (type species) & von Wintzingerode et al. (2001) \\
\hline Family Bogoriellaceae Schumann and Stackebrandt 2000 & Stackebrandt \& Schumann (2000) \\
\hline Genus Bogoriella Groth et al. 1997 (type genus) & Groth et al. (1997a) \\
\hline Bogoriella caseilytica Groth et al. 1997 (type species) & Groth et al. (1997a) \\
\hline Genus Georgenia Altenburger et al. 2002 emend. Li et al. 2007 & Altenburger et al. (2002b); Li et al. (2007) \\
\hline Georgenia muralis Altenburger et al. 2002 (type species) & Altenburger et al. (2002b) \\
\hline $\begin{array}{l}\text { Family Brevibacteriaceae Breed } 1953 \text { (Approved Lists 1980) emend. } \\
\text { Stackebrandt et al. } 1997\end{array}$ & $\begin{array}{l}\text { Breed (1953); Skerman et al. (1980); Stackebrandt } \\
\quad \text { et al. (1997) }\end{array}$ \\
\hline Genus Brevibacterium Breed 1953 (type genus) & Breed $(1953)$ \\
\hline Brevibacterium linens (Wolff 1910) Breed 1953 (type species) & Breed (1953) \\
\hline $\begin{array}{l}\text { Family Cellulomonadaceae Stackebrandt and Prauser } 1991 \text { emend. Stackebrandt } \\
\text { and Schumann } 2000\end{array}$ & $\begin{array}{l}\text { Stackebrandt \& Prauser (1991); Stackebrandt \& } \\
\text { Schumann (2000) }\end{array}$ \\
\hline Genus Cellulomonas Bergey et al. 1923 (type genus) & Bergey et al. (1923) \\
\hline $\begin{array}{l}\text { Cellulomonas flavigena (Kellerman and McBeth 1912) Bergey et al. } 1923 \\
\text { (type species) }\end{array}$ & Bergey et al. (1923) \\
\hline Genus Oerskovia Prauser et al. 1970 (Approved Lists 1980) emend. & Prauser et al. (1970); Skerman et al. (1980); \\
\hline Stackebrandt et al. 2002 & Stackebrandt et al. (2002a) \\
\hline $\begin{array}{l}\text { Oerskovia turbata (Erikson 1954) Prauser et al. } 1970 \text { (Approved Lists 1980) } \\
\text { emend. Stackebrandt et al. } 2002 \text { (type species) }\end{array}$ & $\begin{array}{l}\text { Prauser et al. (1970); Skerman et al. (1980); } \\
\quad \text { Stackebrandt et al. (2002a) }\end{array}$ \\
\hline Family Dermabacteraceae Stackebrandt et al. 1997 & Stackebrandt et al. (1997) \\
\hline Genus Dermabacter Jones and Collins 1989 (type genus) & Jones \& Collins (1988) \\
\hline Dermabacter hominis Jones and Collins 1989 (type species) & Jones \& Collins (1988) \\
\hline Genus Brachybacterium Collins et al. 1988 & Collins et al. (1988) \\
\hline Brachybacterium faecium Collins et al. 1988 (type species) & Collins et al. (1988) \\
\hline Genus Devriesea Martel et al. 2008 & Martel et al. (2008) \\
\hline Devriesea agamarum Martel et al. 2008 (type species) & Martel et al. (2008) \\
\hline Family Dermacoccaceae Schumann and Stackebrandt 2000 & Stackebrandt \& Schumann (2000) \\
\hline Genus Dermacoccus Stackebrandt et al. 1995 (type genus) & Stackebrandt et al. (1995) \\
\hline Dermacoccus nishinomiyaensis (Oda 1935) Stackebrandt et al. 1995 (type species) & Oda (1935); Stackebrandt et al. (1995) \\
\hline Genus Demetria Groth et al. 1997 & Groth et al. (1997b) \\
\hline Demetria terragena Groth et al. 1997 (type species) & Groth et al. (1997b) \\
\hline Genus Kytococcus Stackebrandt et al. 1995 & Stackebrandt et al. (1995) \\
\hline $\begin{array}{l}\text { Kytococcus sedentarius (ZoBell and Upham 1944) Stackebrandt et al. } 1995 \\
\text { (type species) }\end{array}$ & ZoBell \& Upham (1944); Stackebrandt et al. (1995) \\
\hline Family Dermatophilaceae Austwick 1958 & Austwick (1958) \\
\hline Genus Dermatophilus (Van Saceghem 1915) Gordon 1964 (type genus) & Van Saceghem (1915); Gordon (1964) \\
\hline Dermatophilus congolensis (Van Saceghem 1915) Gordon 1964 (type species) & Van Saceghem (1915); Gordon (1964) \\
\hline Genus Kineosphaera Liu et al. 2002 & Liu et al. (2002) \\
\hline Kineosphaera limosa Liu et al. 2002 (type species) & Liu et al. (2002) \\
\hline $\begin{array}{l}\text { Family Intrasporangiaceae Rainey et al. } 1997 \text { emend. Stackebrandt and } \\
\text { Schumann } 2000\end{array}$ & $\begin{array}{l}\text { Stackebrandt et al. (1997); Stackebrandt \& } \\
\text { Schumann (2000) }\end{array}$ \\
\hline Genus Intrasporangium Kalakoutskii et al. 1967 (type genus) & Kalakoutskii et al. (1967) \\
\hline Intrasporangium calvum Kalakoutskii et al. 1967 (type species) & Kalakoutskii et al. (1967) \\
\hline Genus Arsenicicoccus Collins et al. 2004 & Collins et al. (2004) \\
\hline Arsenicicoccus bolidensis Collins et al. 2004 (type species) & Collins et al. (2004) \\
\hline Genus Humibacillus Kageyama et al. 2008 & Kageyama et al. (2008b) \\
\hline Humibacillus xanthopallidus Kageyama et al. 2008 (type species) & Kageyama et al. (2008b) \\
\hline Genus Humihabitans Kageyama et al. 2007 & Kageyama et al. (2007) \\
\hline Humihabitans oryzae Kageyama et al. 2007 (type species) & Kageyama et al. (2007) \\
\hline
\end{tabular}


Table 1. cont.

Taxa

Genus Janibacter Martin et al. 1997

Janibacter limosus Martin et al. 1997 (type species)

Genus Knoellia Groth et al. 2002

Knoellia sinensis Groth et al. 2002 (type species)

Genus Kribbia Jung et al. 2006

Kribbia dieselivorans Jung et al. 2006 (type species)

Genus Lapillicoccus Lee and Lee 2007

Lapillicoccus jejuensis Lee and Lee 2007 (type species)

Genus Marihabitans Kageyama et al. 2008

Marihabitans asiaticum Kageyama et al. 2008 (type species)

Genus Ornithinicoccus Groth et al. 1999

Ornithinicoccus hortensis Groth et al. 1999 (type species)

Genus Ornithinimicrobium Groth et al. 2001

Ornithinimicrobium humiphilum Groth et al. 2001 (type species)

Genus Oryzihumus Kageyama et al. 2005

Oryzihumus leptocrescens Kageyama et al. 2005 (type species)

Genus Phycicoccus Lee 2006

Phycicoccus jejuensis Lee 2006 (type species)

Genus Serinicoccus Yi et al. 2004

Serinicoccus marinus Yi et al. 2004 (type species)

Genus Terrabacter Collins et al. 1989

Terrabacter tumescens (Jensen 1934) Collins et al. 1989 (type species)

Genus Terracoccus Prauser et al. 1997

Terracoccus luteus Prauser et al. 1997 (type species)

Genus Tetrasphaera Maszenan et al. 2000 emend. Ishikawa and Yokota 2006

Tetrasphaera japonica Maszenan et al. 2000 (type species)

Family Jonesiaceae Stackebrandt et al. 1997

Genus Jonesia Rocourt et al. 1987 (type genus)

Jonesia denitrificans (Prévot 1961) Rocourt et al. 1987 (type species)

Family Microbacteriaceae Park et al. 1995 emend. Rainey et al. 1997

Genus Microbacterium Orla-Jensen 1919 (Approved Lists 1980) emend.

Takeuchi and Hatano 1998 (type genus)

Microbacterium lacticum Orla-Jensen 1919 (type species)

Genus Agreia Evtushenko et al. 2001

Agreia bicolorata Evtushenko et al. 2001 (type species)

Genus Agrococcus Groth et al. 1996

Agrococcus jenensis Groth et al. 1996 (type species)

Genus Agromyces Gledhill and Casida 1969 (Approved Lists 1980) emend.

Zgurskaya et al. 1992

Agromyces ramosus Gledhill and Casida 1969 (type species)

Genus Aureobacterium Collins et al. 1983. The genus name Aureobacterium is a later heterotypic synonym of the genus name Microbacterium Orla-Jensen 1919 Aureobacterium liquefaciens Collins et al. 1983 (type species)

Genus Clavibacter Davis et al. 1984

Clavibacter michiganensis (Smith 1910) Davis et al. 1984 (type species)

Genus Cryobacterium Suzuki et al. 1997

Cryobacterium psychrophilum (ex Inoue and Komagata 1976) Suzuki et al. 1997

(type species)

Genus Curtobacterium Yamada and Komagata 1972

Curtobacterium citreum (Komagata and Iizuka 1964) Yamada and Komagata

1972 (type species)

Genus Frigoribacterium Kämpfer et al. 2000

Frigoribacterium faeni Kämpfer et al. 2000 (type species)

Genus Frondicola Zhang et al. 2007

Frondicola australicus Zhang et al. 2007 (type species)

Genus Glaciibacter Katayama et al. 2009

\section{Reference}

Martin et al. (1997)

Martin et al. (1997)

Groth et al. (2002)

Groth et al. (2002)

Jung et al. (2006)

Jung et al. (2006)

Lee \& Lee (2007)

Lee \& Lee (2007)

Kageyama et al. (2008a)

Kageyama et al. (2008a)

Groth et al. (1999a)

Groth et al. (1999a)

Groth et al. (2001)

Groth et al. (2001)

Kageyama et al. (2005)

Kageyama et al. (2005)

Lee (2006)

Lee (2006)

Yi et al. (2004)

Yi et al. (2004)

Collins et al. (1989)

Jensen (1934); Collins et al. (1989)

Prauser et al. (1997)

Prauser et al. (1997)

Maszenan et al. (2000); Ishikawa \& Yokota (2006)

Ishikawa \& Yokota (2006)

Stackebrandt et al. (1997)

Rocourt et al. (1987)

Prévot (1961); Rocourt et al. (1987)

Park et al. (1993); Stackebrandt et al. (1997)

Orla-Jensen (1919); Skerman et al. (1980); Takeuchi

\& Hatano (1998)

Orla-Jensen (1919)

Evtushenko et al. (2001)

Evtushenko et al. (2001)

Groth et al. (1996)

Groth et al. (1996)

Gledhill \& Casida (1969); Skerman et al. (1980);

Zgurskaya et al. (1992)

Gledhill \& Casida (1969)

Collins et al. (1983); Takeuchi \& Hatano (1998)

Collins et al. (1983)

Davis et al. (1984)

Smith (1910); Davis et al. (1984)

Suzuki et al. (1997)

Inoue \& Komagata (1976); Suzuki et al. (1997)

Inoue \& Komagata (1976)

Komagata \& Iizuka (1964); Yamada \& Komagata (1972)

Kämpfer et al. (2000)

Kämpfer et al. (2000)

Zhang et al. (2007b)

Zhang et al. (2007b)

Katayama et al. (2009) 
Table 1. cont.

Taxa

Reference

Glaciibacter superstes Katayama et al. 2009 (type species)

Genus Gulosibacter Manaia et al. 2004

Gulosibacter molinativorax Manaia et al. 2004 (type species)

Genus Humibacter Vaz-Moreira et al. 2008

Humibacter albus Vaz-Moreira et al. 2008 (type species)

Genus Klugiella Cook et al. 2008

Klugiella xanthotipulae Cook et al. 2008 (type species)

Genus Labedella Lee 2007

Labedella gwakjiensis Lee 2007 (type species)

Genus Leifsonia Evtushenko et al. 2000

Leifsonia aquatica (ex Leifson 1962) Evtushenko et al. 2000 (type species)

Genus Leucobacter Takeuchi et al. 1996

Leucobacter komagatae Takeuchi et al. 1996 (type species)

Genus Microcella Tiago et al. 2005 emend. Tiago et al. 2006

Microcella putealis Tiago et al. 2005 (type species)

Genus Microterricola Matsumoto et al. 2008

Microterricola viridarii Matsumoto et al. 2008 (type species)

Genus Mycetocola Tsukamoto et al. 2001

Mycetocola saprophilus Tsukamoto et al. 2001 (type species)

Genus Okibacterium Evtushenko et al. 2002

Okibacterium fritillariae Evtushenko et al. 2002 (type species)

Genus Phycicola Lee et al. 2008

Phycicola gilvus Lee et al. 2008 (type species)

Genus Plantibacter Behrendt et al. 2002

Plantibacter flavus Behrendt et al. 2002 (type species)

Genus Pseudoclavibacter Manaia et al. 2004

Pseudoclavibacter helvolus Manaia et al. 2004 (type species)

Genus Rathayibacter Zgurskaya et al. 1993

Rathayibacter rathayi (Smith 1913) Zgurskaya et al. 1993 (type species)

Genus Rhodoglobus Sheridan et al. 2003

Rhodoglobus vestalii Sheridan et al. 2003 (type species)

Genus Salinibacterium Han et al. 2003

Salinibacterium amurskyense Han et al. 2003 (type species)

Genus Schumannella An et al. 2009

Schumannella luteola An et al. 2009 (type species)

Genus Subtercola Männistö et al. 2000

Subtercola boreus Männistö et al. 2000 (type species)

Genus Yonghaparkia Yoon et al. 2006

Yonghaparkia alkaliphila Yoon et al. 2006 (type species)

Genus Zimmermannella Lin et al. 2004. The genus name Zimmermannella is a later homotypic synonym of the genus name Pseudoclavibacter Manaia et al. 2004 Zimmermannella helvola Lin et al. 2004 (type species)

Family Micrococcaceae Pribram 1929 (Approved Lists 1980) emend. Stackebrandt et al. 1997

Genus Micrococcus Cohn 1872 (Approved Lists 1980) emend. Wieser et al. 2002 (type genus)

Micrococcus luteus (Schroeter 1872) Cohn 1872 (Approved Lists 1980) emend.

Wieser et al. 2002 (type species)

Genus Acaricomes Pukall et al. 2006

Acaricomes phytoseiuli Pukall et al. 2006 (type species)

Genus Arthrobacter Conn and Dimmick 1947 (Approved Lists 1980) emend.

Koch et al. 1995

Arthrobacter globiformis (Conn 1928) Conn and Dimmick 1947 (type species)

Genus Citricoccus Altenburger et al. 2002

Citricoccus muralis Altenburger et al. 2002 (type species)
Katayama et al. (2009)

Manaia et al. (2004)

Manaia et al. (2004)

Vaz-Moreira et al. (2008)

Vaz-Moreira et al. (2008)

Cook et al. (2008)

Cook et al. (2008)

Lee (2007)

Lee (2007)

Evtushenko et al. (2000)

Leifson (1962); Evtushenko et al. (2000)

Takeuchi et al. (1996)

Takeuchi et al. (1996)

Tiago et al. $(2005,2006)$

Tiago et al. (2005)

Matsumoto et al. (2008)

Matsumoto et al. (2008)

Tsukamoto et al. (2001)

Tsukamoto et al. (2001)

Evtushenko et al. (2002)

Evtushenko et al. (2002)

Lee et al. (2008)

Lee et al. (2008)

Behrendt et al. (2002)

Behrendt et al. (2002)

Manaia et al. (2004)

Manaia et al. (2004)

Zgurskaya et al. (1993)

Smith (1913); Zgurskaya et al. (1993)

Sheridan et al. (2003)

Sheridan et al. (2003)

Han et al. (2003)

Han et al. (2003)

An et al. (2008)

An et al. (2008)

Männistö et al. (2000)

Männistö et al. (2000)

Yoon et al. (2006)

Yoon et al. (2006)

Lin et al. (2004)

Lin et al. (2004)

Pribram (1929); Skerman et al. (1980); Stackebrandt et al. (1997)

Cohn (1872); Skerman et al. (1980); Wieser et al. (2002)

Schroeter (1872); Cohn (1872); Skerman et al. (1980); Wieser et al. (2002)

Pukall et al. (2006)

Pukall et al. (2006)

Conn \& Dimmick (1947); Skerman et al. (1980);

Koch et al. (1995)

Conn (1928); Conn \& Dimmick (1947); Koch et al. (1995)

Altenburger et al. (2002a)

Altenburger et al. (2002a) 
Table 1. cont.

Taxa
Genus Kocuria Stackebrandt et al. 1995
Kocuria rosea (Flügge 1886) Stackebrandt et al. 1995 (type species)
Genus Nesterenkonia Stackebrandt et al. 1995 emend. Collins et al. 2002
Nesterenkonia halobia (Onishi and Kamekura 1972) Stackebrandt et al. 1995
(type species)
Genus Renibacterium Sanders and Fryer 1980
Renibacterium salmoninarum Sanders and Fryer 1980 (type species)
Genus Rothia Georg and Brown 1967
Rothia dentocariosa (Onishi 1949 ) Georg and Brown 1967 (type species)
Genus Stomatococcus Bergan and Kocur 1982. The genus name Stomatococcus is
a later heterotypic synonym of the genus name Rothia Georg and Brown 1967
Stomatococcus mucilaginosus Bergan and Kocur 1982
Genus Zhihengliuella Zhang et al. 2007
Zhihengliuella halotolerans Zhang et al. 2007 (type species)

Family Promicromonosporaceae Rainey et al. 1997

Genus Promicromonospora Krassil'nikov et al. 1961 (type genus)

Promicromonospora citrea Krassil'nikov et al. 1961 (type species)

Genus Cellulosimicrobium Schumann et al. 2001 emend. Brown et al. 2006

Cellulosimicrobium cellulans (Metcalfe and Brown 1957) Schumann et al. 2001

(type species)

Genus Isoptericola Stackebrandt et al. 2004

Isoptericola variabilis (Bakalidou et al. 2002) Stackebrandt et al. 2004 (type species)

Genus Myceligenerans Cui et al. 2004

Myceligenerans xiligouense Cui et al. 2004 (type species)

Genus Xylanibacterium Rivas et al. 2004

Xylanibacterium ulmi Rivas et al. 2004 (type species)

Genus Xylanimicrobium Stackebrandt and Schumann 2004

Xylanimicrobium pachnodae (Cazemier et al. 2004) Stackebrandt and Schumann

2004 (type species)

Genus Xylanimonas Rivas et al. 2003

Xylanimonas cellulosilytica Rivas et al. 2003 (type species)

Family Rarobacteraceae Stackebrandt and Schumann 2000
Genus Rarobacter Yamamoto et al. 1988 (type genus)
Rarobacter faecitabidus Yamamoto et al. 1988 (type species)

Family Sanguibacteraceae Stackebrandt and Schumann 2000 Genus Sanguibacter Fernandez-Garayzabal et al. 1995 (type genus) Sanguibacter keddieii Fernandez-Garayzabal et al. 1995 (type species)

\section{Family Yaniellaceae Li et al. 2008*}

Previous illegitimate name: Yaniaceae Li et al. 2005

Genus Yaniella Li et al. 2008 (type genus)*

Previous illegitimate name: Yania Li et al. 2004

Yaniella halotolerans Li et al. 2008 (type species)

Previous illegitimate name: Yania halotolerans Li et al. 2004

\section{Reference}

Stackebrandt et al. (1995)

Flügge (1886); Stackebrandt et al. (1995)

Stackebrandt et al. (1995); Collins et al. (2002)

Onishi \& Kamekura (1972); Stackebrandt et al. (1995)

Sanders \& Fryer (1980)

Sanders \& Fryer (1980)

Georg \& Brown (1967)

Onishi (1949); Georg \& Brown (1967)

Bergan \& Kocur (1982); Collins et al. (2000)

Bergan \& Kocur (1982)

Zhang et al. (2007a)

Zhang et al. (2007a)

Stackebrandt et al. (1997)

Krassil'nikov et al. (1961)

Krassil'nikov et al. (1961)

Schumann et al. (2001); Brown et al. (2006)

Metcalfe \& Brown (1957); Schumann et al. (2001)

Stackebrandt et al. (2004)

Bakalidou et al. (2002); Stackebrandt et al. (2004)

Cui et al. (2004)

Cui et al. (2004)

Rivas et al. (2004)

Rivas et al. (2004)

Stackebrandt \& Schumann (2004)

Cazemier et al. (2003); Stackebrandt \& Schumann (2004)

Rivas et al. (2003)

Rivas et al. (2003)

Stackebrandt \& Schumann (2000)

Yamamoto et al. (1988)

Yamamoto et al. (1988)

Stackebrandt \& Schumann (2000)

Fernandez-Garayzabal et al. (1995)

Fernandez-Garayzabal et al. (1995)

Li et al. (2008)

Li et al. (2005)

Li et al. (2008)

Li et al. (2004)

Li et al. (2008)

Li et al. (2004)
Genera unassigned to a family

Genus Actinotalea Yi et al. 2007

Actinotalea fermentans Yi et al. 2007 (type species)

Genus Demequina Yi et al. 2007

Demequina aestuarii Yi et al. 2007 (type species)

Genus Ruania Gu et al. 2007

Ruania albidiflava Gu et al. 2007 (type species)

Genus Tropheryma La Scola et al. 2001

Tropheryma whipplei La Scola et al. 2001 (type species)
Yi et al. (2007)

Yi et al. (2007)

Yi et al. (2007)

Yi et al. (2007)

Gu et al. (2007)

$\mathrm{Gu}$ et al. (2007)

La Scola et al. (2001)

La Scola et al. (2001)

${ }^{\star}$ The genus Yaniella is in most 16S rRNA gene sequence-based phylogenetic analyses a member of the family Micrococcaceae and it appears debatable whether it deserves the status as the type genus of its own family Yaniellaceae (E. Stackebrandt, W. Ludwig, personal communication). 
genus Demequina which contains a demethylmenaquinone) as the respiratory quinones. Mycolic acids and arabinogalactan are absent and the DNA base composition is higher than $50 \mathrm{~mol} \% \mathrm{G}+\mathrm{C}$.

Many of the genera presently considered to be members of the suborder Micrococcineae were formerly dealt with by the Subcommittees No. 8 on Arthrobacter and Related Organisms and No. 9 on Microbacterium and Related Organisms of the International Committee on Systematic Bacteriology (now the International Committee on Systematics of Prokaryotes, ICSP). Minimal standards for the description of taxa related to the genera Arthrobacter and Microbacterium were proposed by Schumann \& Prauser (1995). These minimal standards are in need of updating in the light of current taxonomic classifications, the numerous descriptions of novel taxa and the new methodological approaches to bacterial systematics. In order to comprehensively describe a new genus or species of the suborder Micrococcineae, to allow a clear identification of the novel taxon and to maintain the taxonomic soundness of the suborder, it is recommended that the following minimal standards are adopted.

\section{General considerations}

The general prerequisites for the description of new taxa and their designation of type genera, type species and type strains have been outlined in the Bacteriological Code (1990 Revision) (Lapage et al., 1992), with several proposals for modifications (e.g. Labeda, 1997, 2000; Tindall, 1999, 2008; Tindall et al., 2006; Tindall \& Garrity, 2008), in previous proposals for minimal standards (e.g. Bernardet et al., 2002) and in the Instructions to Authors of the International Journal of Systematic and Evolutionary Microbiology (http://ijs.sgmjournals.org). Type strains of novel species must be deposited in two publicly accessible culture collections in different countries, as recommended by the Judicial Commission on Prokaryote Nomenclature. For further details regarding the practice of valid publication of names, authors should consult Tindall et al. (2006), Tindall (2008) and Tindall \& Garrity (2008).

It is essential that the source of the strains representing the new taxon is described comprehensively and unambiguously with respect to geographical location (country, region, mountain, lake etc., preferably with geographical coordinates) and origin of the sample (host organism, environmental sample such as type of soil, sediment, depth of water etc.). The conditions of isolation, maintenance and preservation must be reported.

The polyphasic approach, which integrates genomic and phylogenetic information with phenotypic and chemotaxonomic data (Vandamme et al., 1996), is currently considered the general principle for taxonomic conclusions. Minimal standards for the description of new taxa according to Recommendation 30b of the Bacteriological
Code (1990 Revision) (Lapage et al., 1992) have to be established in accordance with this principle.

The differentiation of genera of the suborder Micrococcineae is primarily based on 16S rRNA gene sequence comparisons in combination with chemotaxonomic characteristics. Members of the suborder are often difficult to differentiate by morphology, but show a broad chemotaxonomic diversity (Table 2 ). In many cases, the chemotaxonomic characteristics are consistent with the phylogenetic position of organisms (Fig. 1) and are regarded as important phenotypic traits in the differentiation of genera of this suborder. Therefore chemotaxonomic characteristics need to be carefully analysed and evaluated for descriptions of novel taxa (Stackebrandt \& Schumann, 2006).

Many 'classical' phenotypic characteristics, including morphological, physiological and biochemical features used for the description of the phenotype may be affected by cultural or test conditions. A comparative experimental study of phenotypic characteristics in representatives of putative novel species and of type strains of recognized taxa in the authors' own laboratory rather than comparisons with data reported in the literature is recommended (see also paragraph on cellular fatty acids). This is of particular importance when the organisms to be compared appear highly related on the basis of $16 \mathrm{~S}$ rRNA gene sequences and where the species description is based on only a single strain. The number and significance of differentiating phenotypic characteristics must be sufficiently high in order to delineate the species borders as reliably as possible and to ensure that a new isolate of the species will be phenotypically recognizable.

Several genera of the suborder Micrococcineae (Bogoriella, Demequina, Humibacter, Humihabitans, Ruania, Serinicoccus, Terracoccus etc.) are represented by the type strains of their type species only. The description of new taxa should preferably be based on many isolates from different sources if possible since single strains cannot reflect the full biological diversity of species and genera. However, the description of a novel taxon with extraordinary combinations of characteristics should not be inhibited by the fact that intensive isolation programs have failed to provide additional strains. The description of taxa represented by only a few isolates or even a single strain poses a special challenge as regards the selection of appropriate techniques for characterization.

\section{Minimal standards and recommended characteristics for describing novel genera and species}

The genotypic and phenotypic criteria of the minimal standards for description of genera and species (Table 3) are considered essential for the characterization and differentiation of new members of the suborder Micrococcineae. Additional characteristics that are not 
Table 2. Chemotaxonomic characteristics of genera of the suborder Micrococcineae

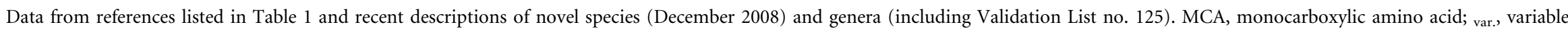

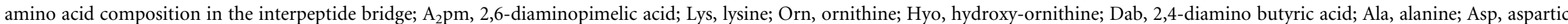

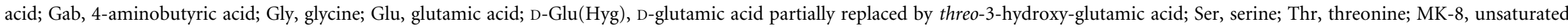

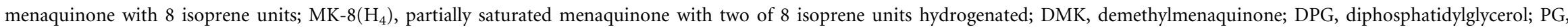

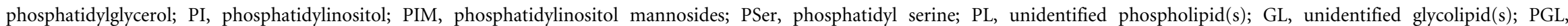

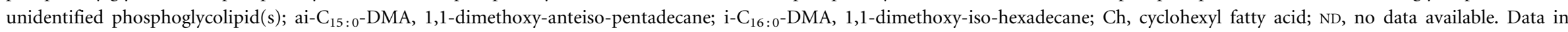
parentheses were reported for only a few species.

\begin{tabular}{|c|c|c|c|c|c|c|c|}
\hline Genus & Diamino acid & $\begin{array}{c}\text { Interpeptide bridge/[amino acid } \\
\text { at position } 3 \text { of the peptide } \\
\text { subunit] }\end{array}$ & Acyl type & $\begin{array}{l}\text { Major respiratory } \\
\text { quinones }\end{array}$ & Polar lipids & $\begin{array}{c}\text { Characteristic cellular } \\
\text { fatty acids }\end{array}$ & $\begin{array}{l}\text { DNA G+C } \\
\text { content } \\
(\text { mol\% })\end{array}$ \\
\hline \multicolumn{8}{|c|}{ Family Beutenbergiaceae } \\
\hline Beutenbergia & L-Lys & L-Glu & Acetyl & MK-8 $\left(\mathrm{H}_{4}\right)$ & PI, DPG, PL & i- $C_{15: 0}$, ai- $C_{15: 0}$ & 71 \\
\hline Salana & L-Orn & L-Glu* & ND & MK-8 $\left(\mathrm{H}_{4}\right)$ & PG, DPG, PL & ai- $C_{15: 0}, C_{14: 0}, C_{16: 0}$ & 75 \\
\hline \multicolumn{8}{|c|}{ Family Bogoriellaceae } \\
\hline Bogoriella & L-Lys & L-Ala-L-Ala-L-Glu & Acetyl & $\mathrm{MK}-8\left(\mathrm{H}_{4}\right)$ & PI, PG, DPG, PL & ai- $C_{15: 0}, \mathrm{i}-\mathrm{C}_{15: 1}, \mathrm{i}-\mathrm{C}_{16: 0}$ & 70 \\
\hline Georgenia & L-Lys & L-Glu or L-Ala-L-Glu & Acetyl & MK-8 $\left(\mathrm{H}_{4}\right)$ & $\begin{array}{l}\text { PG, DPG, PIM, PL, } \\
\text { GL, (PI) }\end{array}$ & $\begin{array}{c}\text { ai- } C_{15: 0}, \text { ai- } C_{15: 1} \dagger, \mathrm{i}-\mathrm{C}_{14: 0}, \\
\text { i- } \mathrm{C}_{16: 0}\end{array}$ & $70-73$ \\
\hline \multicolumn{8}{|c|}{ Family Brevibacteriaceae } \\
\hline $\begin{array}{l}\text { Brevibacterium } \\
\text { Family Cellulom }\end{array}$ & meso- $\mathrm{A}_{2} \mathrm{pm}$ & None & Acetyl & MK-8 $\left(\mathrm{H}_{2}\right)$, MK-7 $\left(\mathrm{H}_{2}\right)$ & PI, PG, DPG, GL, PL & ai- $C_{15: 0}$, ai- $C_{17: 0}$ & $56-71$ \\
\hline Cellulomonas & L-Orn & D-Asp or D-Glu & Acetyl & MK-9 $\left(\mathrm{H}_{4}\right)$, MK- $8\left(\mathrm{H}_{4}\right)$ & $\begin{array}{l}\text { PI, PGL, PG, DPG, } \\
(\mathrm{PE})\end{array}$ & ai- $C_{15: 0}, C_{16: 0}, i-C_{15: 0}$, ai- $C_{17: 0}$ & $69-76$ \\
\hline Oerskovia & L-Lys & L-Thr-D-Asp or L-Thr-D-Glu & Acetyl & MK-9 $\left(\mathrm{H}_{4}\right)$ & PG, DPG, PI & $\begin{array}{c}\text { ai- } \mathrm{C}_{15: 0}, \mathrm{C}_{16: 0}, \mathrm{i}-\mathrm{C}_{15: 0}, \mathrm{C}_{14: 0}, \\
\text { ai- } \mathrm{C}_{17: 0}\end{array}$ & $70-75$ \\
\hline \multicolumn{8}{|c|}{ Family Dermabacteraceae } \\
\hline Dermabacter & meso- $\mathrm{A}_{2} \mathrm{pm}$ & D-Asp-D-Glu $\ddagger$ & ND & MK-9, MK-8, MK-7 & PG, DPG, PL, GL & ai- $C_{17: 0}$, ai- $C_{15: 0}, \mathrm{i}-\mathrm{C}_{16: 0}$ & 62 \\
\hline Brachybacterium & meso- $\mathrm{A}_{2} \mathrm{pm}$ & D-Glu $u_{2} \ddagger$ or D-Asp-D-Glu $\ddagger$ & $\begin{array}{r}\text { Acetyl or } \\
\text { Glycolyl }\end{array}$ & MK-7, MK-8 & PG, DPG, GL, PL & ai- $\mathrm{C}_{15: 0}$, ai- $\mathrm{C}_{17: 0}$ & $68-73$ \\
\hline Devriesea & $m e s o-\mathrm{A}_{2} \mathrm{pm}$ & D-Asp-D-Glu $\neq$ & ND & MK-8, MK-7, MK-9 & PG, PL, GL & $\begin{array}{c}\mathrm{C}_{14: 0}, \mathrm{i}-\mathrm{C}_{15: 0}, \text { ai }-\mathrm{C}_{15: 0}, \mathrm{C}_{16: 0} \\
\quad \mathrm{i}-\mathrm{C}_{16: 0}, \mathrm{i}-\mathrm{C}_{17: 0}, \text { ai- } \mathrm{C}_{17: 0}\end{array}$ & 61 \\
\hline \multicolumn{8}{|c|}{ Family Dermacoccaceae } \\
\hline Dermacoccus & L-Lys & $\begin{array}{l}\text { L-Ser }_{1-2}-\text { D-Glu or } \\
\text { L-Ser }_{1-2}-\text { L-Ala-D-Glu }\end{array}$ & Acetyl & MK- $8\left(\mathrm{H}_{2}\right)$ & PI, PG, DPG & $\mathrm{i}-\mathrm{C}_{17: 0}, \mathrm{i}-\mathrm{C}_{16: 0}$, ai- $\mathrm{C}_{17: 0}, \mathrm{i}-\mathrm{C}_{17: 1}$ & $65-71$ \\
\hline Demetria & L-Lys & L-Ser-D-Asp & Acetyl & MK-8 $\left(\mathrm{H}_{4}\right)$ & PI, PE, PG, DPG, PL & $\mathrm{C}_{18: 1}, \mathrm{C}_{18: 0}, \mathrm{C}_{17: 0}$, ai- $\mathrm{C}_{17: 0}$ & 66 \\
\hline Kytococcus & L-Lys & D-Glu 2 & $\mathrm{ND}$ & MK-8, MK-9, MK-10 & PI, PG, DPG & ai- $\mathrm{C}_{17: 0}, \mathrm{C}_{17: 0}, \mathrm{i}-\mathrm{C}_{17: 1}$ & $68-69$ \\
\hline \multicolumn{8}{|c|}{ Family Dermatophilaceae } \\
\hline Dermatophilus & meso- $\mathrm{A}_{2} \mathrm{pm}$ & None & Acetyl & $\mathrm{MK}-8\left(\mathrm{H}_{4}\right)$ & PG, DPG, PI & $\mathrm{C}_{16: 0}, \mathrm{C}_{15: 0}, \mathrm{C}_{14: 0}$ & $57-59$ \\
\hline Kineosphaera & meso- $\mathrm{A}_{2} \mathrm{pm}$ & None & ND & MK-8 $\left(\mathrm{H}_{4}\right)$ & PG, DPG, PI, PE, PC & $\mathrm{C}_{16: 0}, \mathrm{C}_{17: 1}, \mathrm{C}_{17: 0}$ & 71 \\
\hline
\end{tabular}




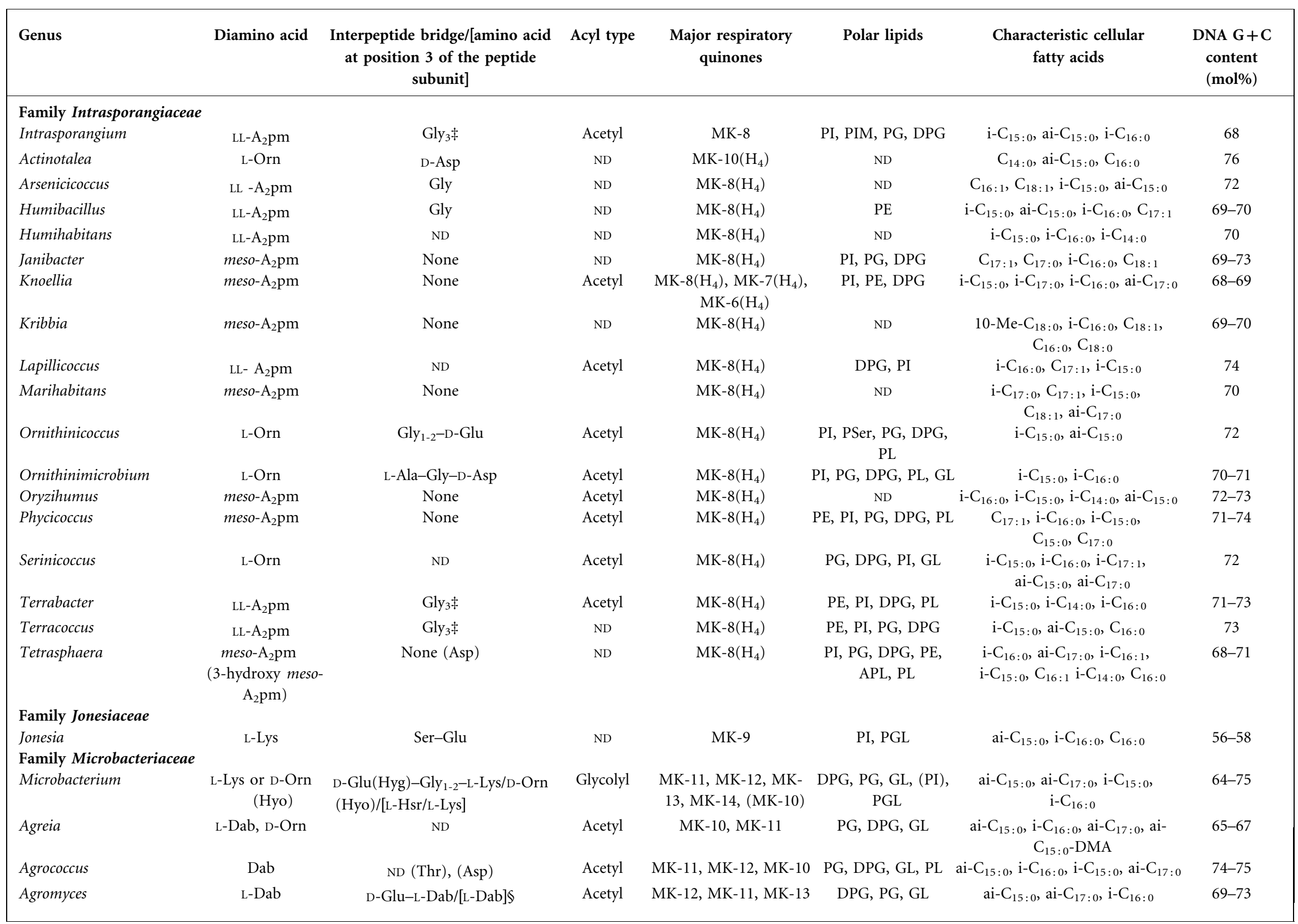


Table 2. cont.

\begin{tabular}{|c|c|c|c|c|c|c|c|}
\hline Genus & Diamino acid & $\begin{array}{c}\text { Interpeptide bridge/[amino acid } \\
\text { at position } 3 \text { of the peptide } \\
\text { subunit] }\end{array}$ & Acyl type & $\begin{array}{c}\text { Major respiratory } \\
\text { quinones }\end{array}$ & Polar lipids & $\begin{array}{l}\text { Characteristic cellular } \\
\text { fatty acids }\end{array}$ & $\begin{array}{l}\text { DNA G }+\mathrm{C} \\
\text { content } \\
(\mathrm{mol} \%)\end{array}$ \\
\hline Clavibacter & L-Dab, D-Dab & D-Glu-D-Dab/[L-Dab] & Acetyl & MK-9, MK-10 & DPG, PG, GL & ai- $C_{15: 0}$, ai- $C_{17: 0}, i-C_{16: 0}$ & $72-74$ \\
\hline Cryobacterium & L-Dab & D-Glu-L-Dab/[L-Dab]§ & Acetyl & MK-10, MK-11, MK-12 & DPG, PG, GL & $\begin{array}{c}\text { ai- } C_{15: 0}, \text { ai- } C_{15: 1} \dagger, \mathrm{i}-\mathrm{C}_{15: 0} \\
\text { ai- } \mathrm{C}_{17: 0}, \mathrm{i}-\mathrm{C}_{16: 0}\end{array}$ & $65-67$ \\
\hline Curtobacterium & D-Orn & D-Glu(Hyg) (-Gly)-D-Orn/[L-Hsr] & Acetyl & MK-9 & PG, GL & $\begin{array}{l}\text { ai- } \mathrm{C}_{15: 0}, \text { ai- } \mathrm{C}_{17: 0}, \mathrm{i}-\mathrm{C}_{16: 0} \\
\mathrm{Ch}^{-}{ }_{17: 0},\left(\text { at } 10{ }^{\circ} \mathrm{C}: \text { ai- }-\mathrm{C}_{15: 1}\right) \dagger\end{array}$ & $66-74$ \\
\hline Frigoribacterium & D-Lys & D-Glu-D-Lys/[L-Hsr] & Acetyl & MK-9 & PG, DPG, GL & $\begin{array}{c}\text { ai- } \mathrm{C}_{15: 0}, \mathrm{i}-\mathrm{C}_{16: 0}, \text { ai }-\mathrm{C}_{15: 0}-\mathrm{DMA}, \\
\left(\text { at }<10{ }^{\circ} \mathrm{C}: \text { ai- }-\mathrm{C}_{15: 1}\right) \dagger\end{array}$ & 71 \\
\hline Frondicola & D-Orn & D-Glu-D-Orn/[L-Hsr] & Acetyl & MK-8, MK-7 & PG, DPG, GL, PL & $\mathrm{C}_{18: 1}, \mathrm{C}_{14: 0} 2-\mathrm{OH}$ & 71 \\
\hline Gulosibacter & D-Orn & $\mathrm{ND}$ & $\mathrm{ND}$ & MK-9 & DPG, PG, GL & ai- $C_{15: 0}, \mathrm{i}-\mathrm{C}_{16: 0}$, ai- $\mathrm{C}_{17: 0}$ & 65 \\
\hline Humibacter & Orn, Dab & $\mathrm{ND}$ & Acetyl & MK-11, MK-12 & ND & $\mathrm{Ch}_{-17: 0}$, ai- $\mathrm{C}_{17: 0}, \mathrm{i}-\mathrm{C}_{16: 0}$ & 68 \\
\hline Klugiella & Lys & ND & Acetyl & MK-12, MK-11 & ND & ai- $C_{15: 0}$, ai- $C_{17: 0}, i-C_{16: 0}$ & 61 \\
\hline Labedella & Orn & ND & Acetyl & MK-10, MK-11 & PG, DPG & ai- $C_{15: 0}, \mathrm{i}-\mathrm{C}_{16: 0}$, ai- $\mathrm{C}_{17: 0}$ & 68 \\
\hline Leifsonia & L-Dab, D-Dab & D-Glu-D-Dab/[L-Dab] & Acetyl & MK-11, MK-10, MK-12 & PG, DPG, GL & $\begin{array}{c}\text { ai- } C_{15: 0}, \text { ai- } C_{17: 0}, \text { i- } C_{16: 0}, \\
\left(C_{-17: 0}\right)\end{array}$ & $66-71$ \\
\hline Leucobacter & $\mathrm{Dab}$ & ND (Thr), (Gab) & Acetyl & MK-11, MK-10 & DPG, PG, GL, PL & ai- $C_{15: 0}$, ai- $C_{17: 0}, i-C_{16: 0}$ & $66-70$ \\
\hline Microcella & Lys or D-Orn & $\mathrm{ND}$ & $\mathrm{ND}$ & MK-12, MK-13, MK-14 & $\mathrm{ND}$ & $\mathrm{i}-\mathrm{C}_{16: 0}$, ai- $\mathrm{C}_{15: 0}, \mathrm{i}-\mathrm{C}_{14: 0}, \mathrm{i}-\mathrm{C}_{15: 0}$ & $67-71$ \\
\hline Microterricola & $\mathrm{Dab}$ & $\mathrm{ND}$ & Acetyl & MK-12, MK-11 & $\mathrm{ND}$ & ai- $\mathrm{C}_{15: 0}$, ai- $\mathrm{C}_{17: 0}$ & 70 \\
\hline Mycetocola & Lys & $\mathrm{ND}$ & Acetyl & MK-10, MK-9, MK-11 & DPG, PG, GL & ai- $\mathrm{C}_{15: 0}$, ai- $\mathrm{C}_{17: 0}$ & $64-70$ \\
\hline Okibacterium & Lys & Glu-Lys/[Hsr] & Glycolyl & MK-10, MK-11 & PG, DPG, GL & ai- $C_{15: 0}$, ai- $C_{17: 0}, \mathrm{i}-\mathrm{C}_{16: 0}, \mathrm{i}-\mathrm{C}_{15: 0}$ & 67 \\
\hline Phycicola & $\mathrm{Dab}$ & D-Glu-Dab/[Dab] & Acetyl & MK-11, MK-10 & DPG, PC, PG, PI & ai- $\mathrm{C}_{15: 0}$, ai- $\mathrm{C}_{17: 0}$ & 70 \\
\hline Plantibacter & L-Dab & D-Glu-L-Dab/[L-Dab]§ & Acetyl & MK-10, MK-11, MK-9 & PG, DPG, GL & ai- $C_{15: 0}, i-C_{16: 0}$, ai- $C_{17: 0}, i-C_{15: 0}$ & $68-70$ \\
\hline Pseudoclavibacter & L-Dab, D-Dab & D-Glu-D- Dab/[L-Dab] & Acetyl & MK-9, MK-8, MK-10 & DPG, PG, GL & ai- $\mathrm{C}_{15: 0}, \mathrm{i}-\mathrm{C}_{16: 0}$, ai- $\mathrm{C}_{17: 0}$ & $62-68$ \\
\hline Rathayibacter & L-Dab & D-Glu-L-Dab/[L-Dab]§ & ND & MK-10 & PG, DPG, GL & ai- $C_{15: 0}$, ai- $C_{17: 0}, i-C_{16: 0}$ & $60-69$ \\
\hline Rhodoglobus & Orn & $\mathrm{ND}$ & $\mathrm{ND}$ & MK-12, MK-11 & $\mathrm{ND}$ & $\begin{array}{l}\text { ai- } C_{15: 0}, \text { i- }-C_{16: 0}, \text { ai }-C_{17: 0} \\
\quad\left(\text { at } 2{ }^{\circ} \mathrm{C}: \text { ai- }-C_{15: 1}\right) \dagger\end{array}$ & 62 \\
\hline Salinibacterium & Orn, Lys & $\mathrm{ND}$ & Acetyl & MK-11, MK-10 & PG, DPG & ai- $C_{15: 0}, \mathrm{i}-\mathrm{C}_{16: 0}, \mathrm{i}-\mathrm{C}_{14: 0}$ & 61 \\
\hline Schumannella & Dab & ND & $\mathrm{ND}$ & MK-11, MK-10, MK-9 & ND & ai- $C_{15: 0}, \mathrm{i}-\mathrm{C}_{16: 0}$, ai- $\mathrm{C}_{17: 0}, \mathrm{i}-\mathrm{C}_{14: 0}$ & 59 \\
\hline Subtercola & $\mathrm{Dab}$ & D-Glu(Hyg)-Dab/[Dab] & Acetyl & MK-9, MK-10 & PG, DPG, PL, GL & $\begin{array}{c}\text { ai- } \mathrm{C}_{15: 0}, \mathrm{i}-\mathrm{C}_{16: 0}, \text { ai- } \mathrm{C}_{17: 0}, \text { ai- } \\
\mathrm{C}_{15: 0} \text {-DMA, i-C } \mathrm{C}_{16: 0} \text {-DMA, } \\
\left(\text { at } 4{ }^{\circ} \mathrm{C}: \text { ai- } \mathrm{C}_{15: 1}\right) \dagger\end{array}$ & $64-68$ \\
\hline Yonghaparkia & $\mathrm{Dab}$ & D-Glu-Dab/[Dab] & $\mathrm{ND}$ & MK-12, MK-11 & PG, DPG, PL, GL & ai- $C_{15: 0}, \mathrm{i}-\mathrm{C}_{16: 0}$, ai- $\mathrm{C}_{17: 0}$ & $71-72$ \\
\hline \multicolumn{8}{|l|}{ Family Micrococcaceae } \\
\hline Micrococcus & L-Lys & Peptide subunit $\neq$, Asp & $\mathrm{ND}$ & $\begin{array}{c}\text { MK- } 8\left(\mathrm{H}_{2}\right) \text { or } \mathrm{MK}-8 \\
\mathrm{MK}-8\left(\mathrm{H}_{2}\right)\end{array}$ & PG, DPG, PI, GL, PL & $\mathrm{ai}-\mathrm{C}_{15: 0}, \mathrm{i}-\mathrm{C}_{15: 0}$ & $69-74$ \\
\hline Acaricomes & L-Lys & $\mathrm{L}-\mathrm{Ala}_{3}$ & $\mathrm{ND}$ & MK-10 $\left(\mathrm{H}_{2}\right)$ & PG, DPG, PI & ai- $\mathrm{C}_{15: 0}$, ai- $\mathrm{C}_{17: 0}$ & 58 \\
\hline $\begin{array}{l}\text { Arthrobacter, globiformis } \\
\text { group }\end{array}$ & L-Lys & $\mathrm{MCA}_{\text {var. }}$ & $\mathrm{ND}$ & $\begin{array}{c}\text { MK-9 }\left(\mathrm{H}_{2}\right), \text { MK- } 8\left(\mathrm{H}_{2}\right), \\
\text { MK-10 }\left(\mathrm{H}_{2}\right)\end{array}$ & $\begin{array}{l}\text { DPG, PG, PI, } \\
\text { DMDG, (PE) }\end{array}$ & $\begin{array}{c}\text { ai- } \mathrm{C}_{15: 0}, \mathrm{i}-\mathrm{C}_{15: 0}, \mathrm{i}-\mathrm{C}_{16: 0}, \text { ai }-\mathrm{C}_{17: 0}, \\
\left(\text { at }<10{ }^{\circ} \mathrm{C}: \text { ai- }-\mathrm{C}_{15: 1}\right) \dagger\end{array}$ & $61-69$ \\
\hline $\begin{array}{l}\text { Arthrobacter, nicotianae } \\
\text { group }\end{array}$ & L-Lys & Ala-Glu, Ser-Glu, Glu or Asp & $\mathrm{ND}$ & MK-8, MK-9, MK-10 & $\begin{array}{l}\text { DPG, PG, PI, } \\
\text { DMDG }\end{array}$ & ai- $\mathrm{C}_{15: 0}$, ai- $\mathrm{C}_{17: 0}$ & $58-66$ \\
\hline
\end{tabular}


Table 2. cont

\begin{tabular}{|c|c|c|c|c|c|c|c|}
\hline Genus & Diamino acid & $\begin{array}{c}\text { Interpeptide bridge/[amino acid } \\
\text { at position } 3 \text { of the peptide } \\
\text { subunit] }\end{array}$ & Acyl type & $\begin{array}{c}\text { Major respiratory } \\
\text { quinones }\end{array}$ & Polar lipids & $\begin{array}{c}\text { Characteristic cellular } \\
\text { fatty acids }\end{array}$ & $\begin{array}{l}\text { DNA G+C } \\
\text { content } \\
(\text { mol } \%)\end{array}$ \\
\hline Citricoccus & L-Lys & Gly-Glu & ND & $\begin{array}{c}\text { MK-9 }\left(\mathrm{H}_{2}\right), \text { MK-7 }\left(\mathrm{H}_{2}\right), \\
\text { MK- } 8\left(\mathrm{H}_{2}\right)\end{array}$ & $\begin{array}{l}\text { DPG, PG, PI, } \\
\text { PL, GL }\end{array}$ & ai- $C_{15: 0}$, ai- $C_{17: 0}, i-C_{15: 0}, i-C_{16: 0}$ & $63-68$ \\
\hline Kocuria & L-Lys & $\mathrm{L}-\mathrm{Ala}_{3-4}$ & ND & $\begin{array}{c}\text { MK-7 }\left(\mathrm{H}_{2}\right), \text { MK- } 8\left(\mathrm{H}_{2}\right), \\
\text { MK-9( }\left(\mathrm{H}_{2}\right)\end{array}$ & $\begin{array}{l}\text { DPG, PG, (PI, PL, } \\
\text { GL) }\end{array}$ & ai- $C_{15: 0}$, ai- $C_{17: 0}, i-C_{15: 0}$ & $60-75$ \\
\hline Nesterenkonia & L-Lys & Gly-L-Glu or L-Glu or Gly-Asp & ND & MK-8, MK-9, MK-7 & DPG, PG, PI, PL, GL & ai- $C_{15: 0}$, ai- $C_{17: 0}, i-C_{16: 0}$ & $64-72$ \\
\hline Renibacterium & L-Lys & L-Ala-Glyll & ND & MK-9, MK-10 & DPG, GL & ai- $\mathrm{C}_{15: 0}$, ai- $\mathrm{C}_{17: 0}$ & $52-54$ \\
\hline Rothia & L-Lys & $\mathrm{Ala}_{3}, \mathrm{Ala}, \mathrm{Ser}, \mathrm{Gly}$ or Gly-Ala & Acetyl & 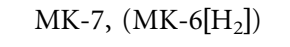 & DPG, PG & ai- $C_{15: 0}$, ai- $C_{17: 0}, \mathrm{i}-\mathrm{C}_{16: 0}, \mathrm{C}_{16: 0}$ & $49-60$ \\
\hline Zhihengliuella & L-Lys & L-Ala-L-Glu & $\mathrm{ND}$ & MK-9, MK-10, MK-8 & PG, DPG, PI, PL, GL & ai- $\mathrm{C}_{15: 0}, \mathrm{i}-\mathrm{C}_{15: 0}$ & 67 \\
\hline \multicolumn{8}{|c|}{ Family Promicromonosporaceae } \\
\hline Promicromonospora & L-Lys & L-Ala-D-Glu & ND & MK-9 $\left(\mathrm{H}_{4}\right)$ & $\begin{array}{l}\text { DPG, PG, PGL, PL, } \\
\text { GL }\end{array}$ & ai- $C_{15: 0}, \mathrm{i}-\mathrm{C}_{16: 0}, \mathrm{C}_{16: 0}$, ai- $\mathrm{C}_{17: 0}$ & $70-75$ \\
\hline Cellulosimicrobium & L-Lys & D-Ser-D-Asp & $\mathrm{ND}$ & MK-9 $\left(\mathrm{H}_{4}\right)$ & ND & ai- $C_{15: 0}, \mathrm{i}-\mathrm{C}_{16: 0}, \mathrm{C}_{16: 0}, \mathrm{i}-\mathrm{C}_{15: 0}$ & 74 \\
\hline Isoptericola & L-Lys & D-Asp or D-Glu & Acetyl & MK-9 $\left(\mathrm{H}_{4}\right)$ & PG, DPG, PI, PL & $\begin{array}{c}\text { ai- } C_{15: 0}, \mathrm{i}-\mathrm{C}_{15: 0}, \mathrm{C}_{14: 0}, \mathrm{C}_{16: 0} \\
\text { i- } \mathrm{C}_{16: 0}, \text { ai- }-\mathrm{C}_{17: 0}\end{array}$ & $70-72$ \\
\hline Myceligenerans & L-Lys & L-Thr-D-Glu & Acetyl & MK-9 $\left(\mathrm{H}_{4}\right)$, MK-9 $\left(\mathrm{H}_{6}\right)$ & PG, DPG, PI, PL, GL & ai- $\mathrm{C}_{15: 0}, \mathrm{i}-\mathrm{C}_{15: 0}$ & 72 \\
\hline Xylanibacterium & L-Lys & L-Ala-D-Glu & $\mathrm{ND}$ & MK-9 $\left(\mathrm{H}_{4}\right)$, MK-8 $\left(\mathrm{H}_{4}\right)$ & PG, DPG, PI, PIM & ai- $C_{15: 0}, \mathrm{i}-\mathrm{C}_{15: 0}, \mathrm{C}_{16: 0}, \mathrm{C}_{14: 0}$ & 72 \\
\hline Xylanimicrobium & L-Lys & L-Ser-D-Glu & Acetyl & MK-9 $\left(\mathrm{H}_{4}\right)$ & PG, DPG, PI, 3PL & ai- $C_{15: 0}, i-C_{15: 0}, C_{16: 0}, C_{14: 0}$ & 70 \\
\hline Xylanimonas & L-Lys & D-Asp & ND & MK-9 $\left(\mathrm{H}_{4}\right)$, MK- $8\left(\mathrm{H}_{4}\right)$ & PG, DPG, PI, PIM & ai- $\mathrm{C}_{15: 0}, \mathrm{i}-\mathrm{C}_{15: 0}$ & 73 \\
\hline $\begin{array}{l}\text { Family Rarobactera } \\
\text { Rarobacter } \\
\text { Family Sanguibacte }\end{array}$ & L-Orn & Ser-Glu or Glu & Acetyl & MK-9 & ND & ai- $C_{15: 0}, \mathrm{i}-\mathrm{C}_{16: 0}, \mathrm{C}_{14: 0}$ (aerobic) & $65-66$ \\
\hline $\begin{array}{l}\text { Sanguibacter } \\
\text { Family Yaniellacea }\end{array}$ & L-Lys & Ser-D-Glu & ND & MK-9 $\left(\mathrm{H}_{4}\right)$ & $\mathrm{ND}$ & ai- $C_{15: 0}, C_{16: 0}, C_{14: 0}$ & $69-73$ \\
\hline \multicolumn{7}{|c|}{ Genera unassigned to a family } & $53-58$ \\
\hline Actinotalea & L-Orn & D-Asp & ND & MK-10 $\left(\mathrm{H}_{4}\right)$ & $\mathrm{ND}$ & $\mathrm{C}_{14: 0}$, ai- $\mathrm{C}_{15: 0}, \mathrm{C}_{16: 0}$ & 76 \\
\hline Demequina & L-Orn & $\mathrm{ND}$ & ND & DMK-9 $\left(\mathrm{H}_{4}\right)$ & PI, DPG, PL & ai- $C_{15: 0}$, ai- $C_{15: 1} \dagger, C_{16: 0}$, ai- $C_{17: 0}$ & 67 \\
\hline Ruania & L-Lys & Gly-L-Glu 2 & ND & MK-8 $\left(\mathrm{H}_{4}\right)$ & PG, DPG, GL & ai- $\mathrm{C}_{15: 0}$, ai- $\mathrm{C}_{17: 0}, \mathrm{i}-\mathrm{C}_{16: 0}$ & 70 \\
\hline Tropheryma & $\mathrm{ND}$ & $\mathrm{ND}$ & ND & $\mathrm{ND}$ & $\mathrm{ND}$ & $\mathrm{ND}$ & 59 \\
\hline
\end{tabular}

${ }^{\star}$ L-Ser occupies position 1 of the peptide subunit.

$\dagger$ The monounsaturated 12-methyl-tetradecenoic acid (ai- $\mathrm{C}_{15: 1}$ ) may also be present in organisms of other genera when grown at temperatures below $10{ }^{\circ} \mathrm{C}$.

\$Glycine or glycine amide bound to $\alpha$-carboxyl group of glutamic acid at position 2 of peptide subunit.

\$eptidoglycan structure supposed on the basis of data from Sasaki et al. (1998) and Behrendt et al. (2002).

IID-Alanine amide bound to $\alpha$-carboxyl group of glutamic acid at position 2 of peptide subunit. 


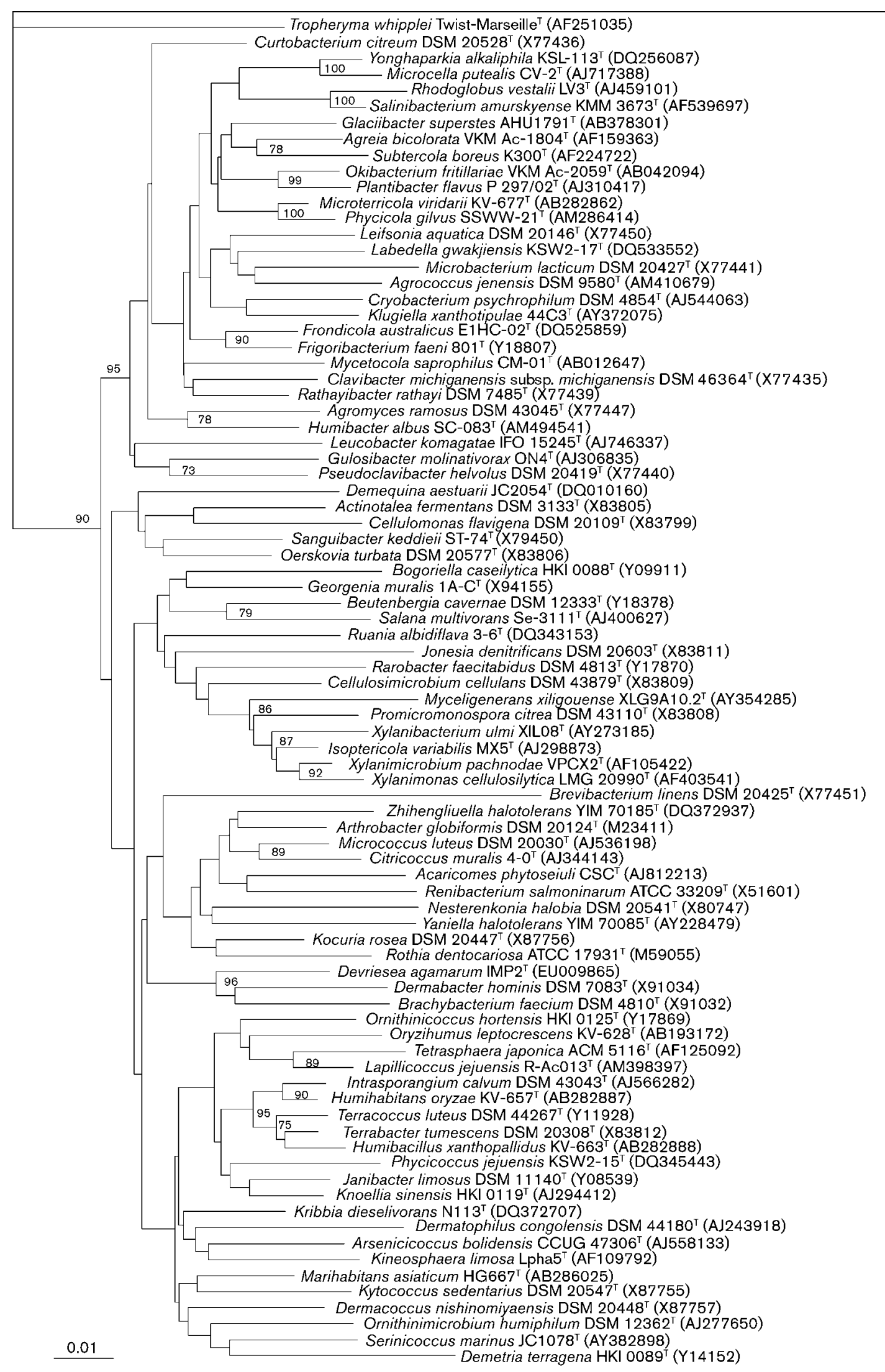


Fig. 1. Neighbour-joining tree showing the phylogenetic relationship of type strains of type species currently classified in the suborder Micrococcineae based on 16S rRNA gene sequences. Bootstrap values (expressed as percentages of 1000 replications) are given at branch points; only values $>70 \%$ are shown. Bacillus subtilis subsp. subtilis $\mathrm{DSM}_{10^{\top}}$ was used as outgroup. Bar, 0.01 substitutions per nucleotide position.

ined in most laboratories are recommended in order to support the differentiation of special groups (Table 4). Taxonomists should feel positively encouraged to apply additional taxonomic methods to supplement those specified here and to continue to search for novel tools that are useful for the differentiation of taxa within this suborder.

\section{CULTURAL AND BIOCHEMICAL CRITERIA}

\section{Colony appearance}

Most of the 'classical' taxonomic characteristics used and recommended for the description of genera and species of the suborder Micrococcineae are the same as those employed for many other bacteria and are available from the literature (e.g. Smibert \& Krieg, 1994). Some characteristics and methods which reflect the specificity of the suborder under consideration are outlined below.

The colony characteristics, including colour, shape, diameter, edge, elevation, surface, consistency and transpar- ency, penetration into agar, etc., may serve for the (preliminary) differentiation of species when observed under standardized conditions (Bergey's Manual; Sneath et al., 1986). The composition of media and growth conditions must be specified, since the colony characteristics (e.g. colony colours of related species) tend to change and depend on the growth conditions.

Growth on agar media supplemented with vitamins, Casitone (milk) and yeast extract, as well as incubation in full daylight, often induce or enhance pigment formation (Koyama et al., 1974; Vidaver \& Davis, 1988; Holt \& Krieg, 1994; Trutko et al., 2005). Attention must be paid to controlling $\mathrm{pH}$ values since deviations from a given pH may markedly alter the colony colour (Turner \& Messenger, 1986). When organisms with alkaliphilic (alkalitolerant) or acidophilic (acidotolerant) properties and their relatives that prefer neutral $\mathrm{pH}$ values are compared, the colony colour should be tested at different $\mathrm{pH}$ values. For those representatives of the suborder which form aerial mycelia, the use of diagnostic ISP media (Shirling \& Gottlieb, 1966) is often appropriate.

Table 3. Minimal standards required for the description of genera and species classified in the suborder Micrococcineae

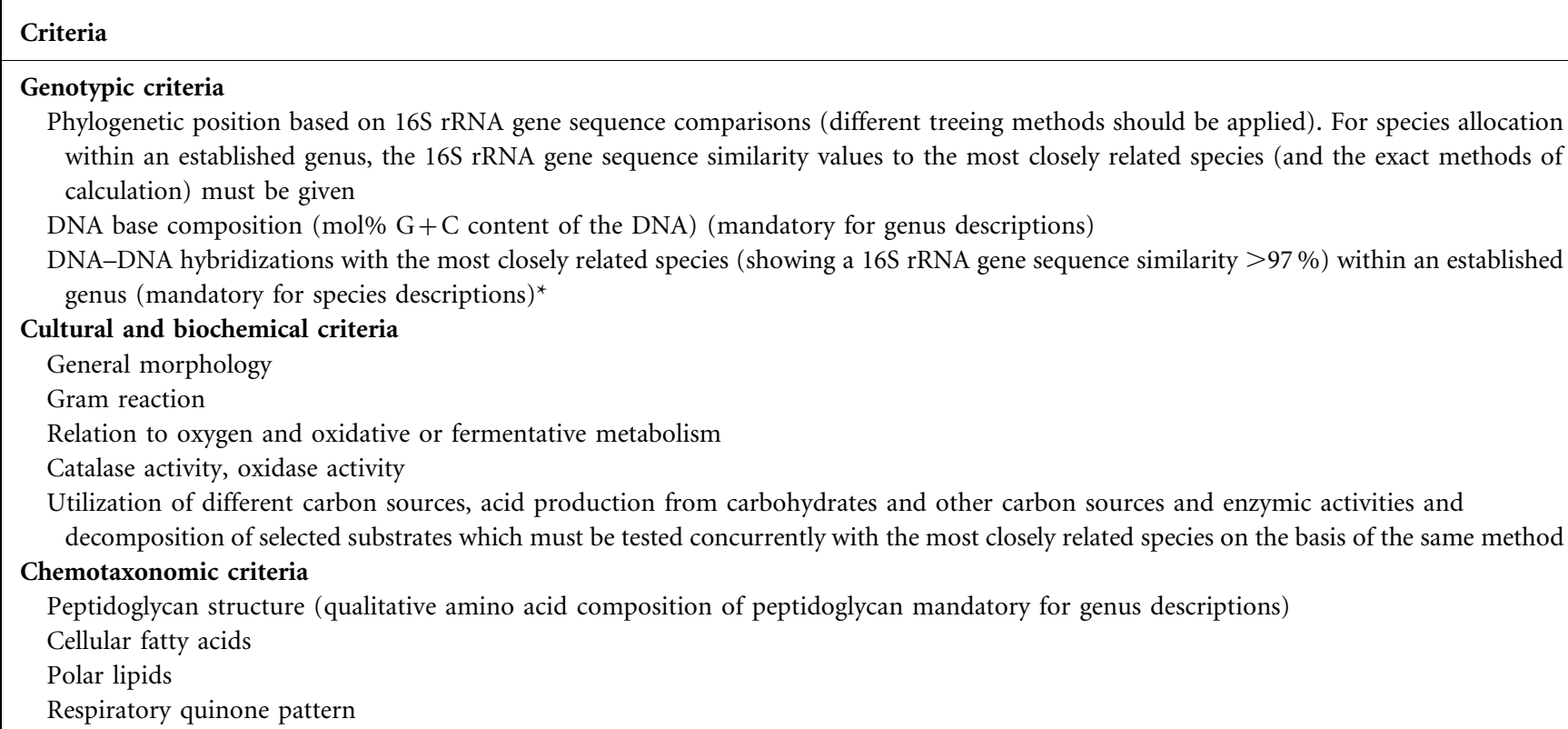

${ }^{*}$ Within the genus Microbacterium, it has been shown that the $16 \mathrm{~S}$ rRNA gene sequence similarity $<98 \%$ may justify a separate species status. In these cases DNA-DNA hybridizations may not be necessary, provided that there is clear evidence that the strain(s) under study is (are) phenotypically clearly different from the most closely related species on the basis of at least five traits which must have been studied concurrently. Clear evidence may be provided by examination of several strains for which non-clonal relatedness was demonstrated. Species identity and nonclonal relatedness may be demonstrated by genomic fingerprinting (high degree of similarity but differences still present in the banding patterns). 
Table 4. Recommended characteristics for characterization and differentiation of genera and species classified in the suborder Micrococcineae

\begin{tabular}{|l|}
\hline Characteristic \\
\hline Cell-wall sugars \\
Acyl type of peptidoglycan \\
Polyamines \\
Total protein profiles \\
Presence of cell-wall teichoic acids and components of cell-wall \\
polysaccharides \\
Sequences of housekeeping genes, multilocus sequence analysis \\
DNA typing patterns \\
FT-IR spectroscopy \\
MALDI/TOF mass spectrometry \\
Pigments \\
Terminal oxidase pattern of respiratory chain \\
Cytochrome and haem composition
\end{tabular}

\section{Morphology}

The notion of the taxonomic value of morphological characters in the classification and differentiation of genera and species in the group under consideration has undergone changes in recent decades.

The importance of morphological characteristics seems to increase for genera since the range of available chemotaxonomic generic criteria appears insufficient for the discrimination of some phylogenetically neighbouring coherent groups for which generic status is claimed (for examples see IJSEM, recent publications). Generalized terms such as 'cocci', 'irregular rods', 'coryneform morphology' and 'nocardioform morphology' are currently widely used in the descriptions of novel genera.

However, for both genera and species, detailed descriptions of the morphology must be provided, including cell size and shape, both at earlier and later growth phases, the type of cell division, cell arrangements, the formation of substrate (primary) and aerial (secondary) mycelium and their fragmentation, and the production and characterization of arthrospores or, if appropriate, other resting cells. As some representatives of the suborder Micrococcineae form spores (arthrospores), e.g. species of the genera Arthrobacter (Tanaka et al., 2001) and Myceligenerans (Cui et al., 2004), it is recommended that it should be stated precisely which kind of spores or resting cells are observed and that the term 'non-endospore-forming' rather than 'non-spore-forming' is used in relevant cases. It is recommended that morphological changes during growth should be tested and noted and that the presence (or absence) of a specific life cycle should be determined. All of the above characteristics should be examined on at least two appropriate agar media of different compositions (e.g. rich in organics as well as chemically defined). The use of relatively old cultures or resting cells is preferable for inoculation in order to synchronize the development of subsequent populations. It is recommended that light or electron micrographs of the culture are presented at different growth phases, particularly for the type strains of the type species of newly described genera.

\section{Motility}

The simplest method to examine motility is the 'hangingdrop method'. Motility can be concluded from the presence of flagella as demonstrated by electron microscopy. Additional methods to test for motility and the formation of flagella were proposed by Holt \& Krieg (1994). The inoculation and testing conditions may be important for some groups. Good results are usually obtained for cultures on semi-solid agar media (agar, 0.2$0.4 \%)$ obtained after inoculation with relatively old cells (1-2 weeks) from agar media. Since not all cells in a population produce flagella, a sample taken from the periphery of colonies is preferable. It should be taken into account that in many representatives of the suborder Micrococcineae, flagella are formed at a later growth phase, i.e. when the cells are at the division stage and/or when the first generations of cells have already consumed the nutrient compounds around the colonies. Even for rapidly growing organisms, it is recommended that motility is examined for a growth period of up to 7-10 days. It should also be taken into account that high temperatures, the presence of glucose or low humidity may inhibit the formation of flagella (Holt \& Krieg, 1994) and that cells may lose flagella during sample preparation for electron microscopy. It should be emphasized that the absence of flagella does not necessarily mean that the cells are nonmotile. Members of the suborder may possess other, not yet fully elucidated mechanisms of motion, e.g. via pili ('twitching motility'). The method used for testing motility and the type of movement observed must be clearly stated.

\section{Gram reaction}

Although members of the suborder Micrococcineae belong to the Gram-positive bacteria in terms of cell-wall structure, the staining reaction may be negative under special circumstances and differentiation between the terms 'Gram reaction' and 'Gram type' is necessary (Wiegel, 1981). Negative or indistinct Gram-stain has been reported for some members of the suborder, e.g. the family Microbacteriaceae, even in relatively young cultures. It is recommended that cultures should be subjected to the Gram staining procedure just after growth has become visible and that staining is tested again at a later exponential growth phase. As Gram-positive bacteria are in general not lysed by $3 \% \mathrm{KOH}$, this simple test is recommended as an additional criterion for the classification of the Gram-reaction status of a novel strain (Ryu, 1938). The test method must be clearly stated.

\section{Growth requirements}

The data on growth requirements characterize an organism and are essential for the determination of its optimal 
cultivation. Suitable media that are as different as possible, the necessary additives (vitamins and other growth factors, extracts, salt, etc.) and the range and optima of $\mathrm{pH}$ and growth temperature must be precisely documented. Some useful recommendations for the description of alkaliphilic and alkalitolerant organisms are outlined by Sorokin (2005).

\section{Relationship with oxygen and oxidative or fermentative metabolism}

Most members of the suborder Micrococcineae are strict aerobes and are characterized by the oxidative type of metabolism. There are also organisms which grow both under aerobic and anaerobic conditions and display the fermentative type of metabolism in addition to the oxidative type (e.g. representatives of the genus Oerskovia). Besides the aforementioned groups, there are also the microaerophilic representatives, which require low concentrations of oxygen for optimal growth (e.g. Agromyces ramosus) and this characteristic should be noted whenever appropriate. The examination of the capability of an organism to grow in an anaerobic chamber is recommended to demonstrate its relationship with oxygen. Anaerobic chambers are also suited to test the influence of alternative electron acceptors. For testing fermentative properties (oxidative or fermentative utilization of glucose), the oxidation-fermentation test (O/F-test, HughLeifson test) is generally accepted (Leifson, 1962; Smibert \& Krieg, 1994). For testing microaerophilic growth, stab cultures in semi-liquid media (0.2-0.4\% agar) can be used. Microaerophilic growth occurs primarily as a distinct or diffuse band below the agar surface (Gledhill \& Casida, 1969; Smibert \& Krieg, 1994).

\section{Catalase activity}

Almost all tested organisms of the considered group possess catalase activity as the main factor inactivating reactive oxygen. To test for presence of catalase, the standard method employing $3 \% \mathrm{H}_{2} \mathrm{O}_{2}$ is recommended. Although the method is very simple, it is necessary to follow exactly the general recommendations outlined by Smibert \& Krieg (1994). In the case of a negative catalase test, it is advisable to characterize other factors that may be preventing oxygen damage as they might turn out to be differentiating characteristics for the organism under study.

\section{Oxidase activity}

The classical 'oxidase test' (Smibert \& Krieg, 1994) with $N, N, N^{\prime}, N^{\prime}$-tetramethyl-p-phenylenediamine (most frequently used in this group) or with $N, N$-dimethyl-pphenylendiamine differentiates two types of aerobic respiratory chains (Unden, 1999). As some organisms grown under different conditions or at different growth stages may show different reactions with $N, N, N^{\prime}, N^{\prime}-$ tetramethyl- $p$-phenylenediamine, oxidase activity should be examined in young, actively growing cultures from agar media. The term 'negative oxidase reaction with $N, N, N^{\prime}, N^{\prime}$-tetramethyl- $p$-phenylenediamine' is recommended instead of 'oxidase-negative', since all aerobic bacteria have oxidases in the respiratory chains. The test method and growth conditions must be clearly stated.

Compared with the simple 'oxidase test', the determination of the terminal oxidase pattern may provide more information on respiratory chains. This characteristic has not been used regularly for taxonomic purposes. However, available data show that it may be helpful for the differentiation of some species and genera of the family Microbacteriaceae. For instance, species of the genus Plantibacter produce only the cytochrome oxidase $a a_{3}$, while the members of the genus Rathayibacter synthesize cytochrome oxidase $b b_{3}$ or both $b b_{3}$ and $a a_{3}$, depending on growth conditions. Some quinole oxidases, e.g. $b o_{3}$ or $b b_{3}$, may be also indicative of species (Trutko et al., 2003). On the other hand, the $b d$-type oxidases seem to be of little significance for differentiation as they are synthesized at relatively low oxygen concentrations in all organisms tested so far. Growth conditions for testing this property should be standardized. The methods of determination of the terminal oxidase patterns are based on spectrophotometry (preliminary spectral characteristics) and chromatography (Trutko et al., 2003).

\section{Utilization of different carbon sources}

Records of the utilization of different carbon sources, including sugars, organic acids, amino acids, etc., as sole carbon source for growth are valuable phenotypic traits in the characterization and delineation of most species within the genera of the suborder Micrococcineae. Several slightly varying basal media can be recommended for different groups of organisms (see e.g. Shirling \& Gottlieb, 1966; Smibert \& Krieg, 1994; recent publications on particular genera). Although the use of commercial test systems for the examination of the physiological characteristics of novel organisms has been controversial (Whiley \& Kilian, 2003; Stackebrandt et al., 2002b), their use is considered acceptable as these kits have been employed in the descriptions of many novel taxa of the suborder due to their ease of use and speed of handling. For comparative analyses it is, however, necessary to study all organisms concurrently with the same tests. Otherwise the data cannot be compared.

The utilization of organic acids is examined either by testing growth on carbon-free basal media supplemented with the compound to be tested or by classical Simmons' citrate tests (basal medium free of additional carbon sources; bromothymol blue indicator) (Smibert \& Krieg, 1994). For some groups, the basal medium should be supplemented with required additives (vitamins, salts, traces of amino acids, etc.) in order to obtain unambiguous results.

The number and type of carbon sources tested may vary depending on the group of organisms. 


\section{Acid production from carbohydrates and other carbon sources}

The methods for the examination of these properties have been described by Smibert \& Krieg (1994), Gordon \& Mihm (1957) and in publications on particular genera. The test for acid production is performed under aerobic conditions. The following sources can be recommended: D-glucose, L-arabinose, raffinose, L-rhamnose, D-ribose, salicin, sucrose, myo-inositol, D-mannitol, glycerol.

The test media should meet the growth requirements of the particular organism. It is recommended that the minimal concentration of the $\mathrm{pH}$ indicator is used since the usually recommended concentrations (developed for other groups of organisms) may inhibit the growth of representatives of the suborder Micrococcineae, in particular of those of the family Microbacteriaceae.

With respect to this and the groups of characteristics mentioned above, it should be noted that both the terms 'utilization of carbon sources' and 'acid production from ...', which are usually used to circumscribe the respective features of members of the suborder Micrococcineae, are covered by the term 'utilization' and there is some confusion over this issue (and hence with the interpretation of results). Though the tests 'growth on sole carbon source' and 'acid production from ...' (carbon-free basal medium) often give the same positive or negative result, they reflect different features of the organisms. Besides, the terms 'utilization of sugars' and 'acid production from ...' are employed to report the results obtained using basal media supplemented with additional carbon sources, e.g. tryptone (API Coryne system, bioMérieux). In addition, the $\mathrm{pH}$ indicators (phenol red or bromothymol blue) most frequently used to test acid production show clear positive reactions at somewhat different $\mathrm{pH}$ values (6.8 and 6.0, respectively).

Comparisons of data generated by different methods or of author's own data with those from the literature often lead to confusion because of conflicting results. The principles of the tests must be taken into account and the results properly interpreted and described.

\section{Enzymic activities and decomposition of selected substrates}

Enzymic activities are used in almost all groups of the suborder for the circumscription of species and also of genera (e.g. Cellulomonas) and are determined by using particular organic substrates (e.g. aesculin, cellulose, starch, Tweens). It must be clearly indicated which method or commercial test system was applied for testing enzymic activities. The number of activities to be examined for unambiguous delineation of species may vary depending on the group of organisms.
The following minimal set of activities is recommended:

- Nitrate reduction determined by the sulfanilic acid and alpha-naphthylamine method and confirmed with zinc dust (Barrow \& Feltham, 1993).

- Urease activity determined on Christensen agar (Christensen, 1946). The red-violet colour of inoculated agar is interpreted as a positive result.

- Arginine dihydrolase activity tested in tubes containing Møller medium (Møller, 1955), both with and without a covering layer of sterile paraffin oil. Tests should be read daily for a period of 5 days. Development of a violet colour is recorded as a positive result.

- Ornithine decarboxylase activity determined using basal medium with $1 \%(\mathrm{w} / \mathrm{v})$ L-ornithine dihydrochloride (Smibert \& Krieg, 1994).

- Alkaline phosphatase activity determined according to Smibert \& Krieg (1994).

It is recommended that decomposition (hydrolysis) is tested for the following minimal set of substrates according to methods described by Smibert \& Krieg (1994): aesculin, casein, cellulose, hypoxanthine, xanthine, starch, L-tyrosine, Tween-60 and Tween-80.

\section{$\mathrm{H}_{2} \mathrm{~S}$ production}

The ability to produce $\mathrm{H}_{2} \mathrm{~S}$ is determined by using a growth medium with peptone (rich in organic sulfur) or liquid medium containing $0.05 \%$ cysteine. The latter medium should be preferred as some members of the suborder Micrococcineae display a positive result only if cysteine is used as substrate. Sterile filter strips impregnated with lead acetate are used as the indicator (blacking is regarded as a positive reaction due to the formation of lead sulfide) (Smibert \& Krieg, 1994).

\section{Tolerance of $\mathrm{NaCl}$ and salt requirement}

Representatives of many species and genera of the suborder Micrococcineae are well differentiated with respect to their salinity requirements. Tolerance of high concentrations of $\mathrm{NaCl}$ has been reported for some members of the suborder, e.g. members of the genus Nesterenkonia, Yaniella halotolerans (up to $25 \% \mathrm{NaCl}$; Li et al., 2004, 2008) and members of the genus Brevibacterium (up to $18 \% \mathrm{NaCl}$; Gavrish et al., 2004). The tolerance of lower salt concentrations clearly differentiates species of many genera commonly known to be non-halotolerant. The ability to grow at different concentrations of $\mathrm{NaCl}$ should be tested in organisms of all new taxa, particularly when strains have been isolated from marine environments, saline and alkaline soils and various desert biotopes, as well as ice and frozen soils or sediments. It is also advisable to evaluate accurately whether particular organisms are either halotolerant or halophilic. A liquid growth medium with a minimal content of essential salts is preferable for testing tolerance to $\mathrm{NaCl}$ and the salt requirement. 


\section{CHEMOTAXONOMIC CRITERIA}

\section{Peptidoglycan structure}

The highly diverse peptidoglycan structures of members of the suborder Micrococcineae (Table 2) can be subdivided according to the following criteria:

- type of diagnostic diamino acid

- type of cross-linkage (A or B according to Schleifer \& Kandler, 1972)

- detailed structure, including amino acid sequence of the interpeptide bridge (see Schleifer \& Kandler, 1972 and http://www.dsmz.de/microorganisms/main.php? content_id=35).

Peptidoglycan structures are an important tool for the differentiation of members of the suborder Micrococcineae at the genus level and also at the species level within several genera (e.g. Arthrobacter, Microbacterium, Cellulomonas, Oerskovia, Brachybacterium and Nesterenkonia). On the other hand, the elucidation of the detailed peptidoglycan structure according to Schleifer \& Kandler (1972) and Schleifer (1985) is a rather demanding task that requires specific experience and cannot be performed by all laboratories. For differentiation at the genus level, it is necessary to examine as a minimal requirement, the type of the diagnostic diamino acid (ornithine, lysine, diaminobutyric acid, diaminopimelic acid isomers, hydroxylated diamino acids) and other amino acids included in the peptidoglycan. The molar ratio of amino acids in peptidoglycan hydrolysates should be determined by using automated amino acid analysers (Schleifer \& Kandler, 1972), HPLC (e.g. Lin et al., 2004), GC (e.g. MacKenzie, 1987) or GC/MS (e.g. MacKenzie, 1984) since quantitative data allow the discrimination between many peptidoglycan structures. Additional investigations such as enantiomeric analysis of amino acids by GC (e.g. Frank et al., 1980) or by HPLC (e.g. Sasaki et al., 1998), the amino acid sequence of the interpeptide bridge and the determination of the $\mathrm{N}$ terminal amino acid of the interpeptide bridge (Schleifer, 1985) also provide helpful information for the elucidation of the detailed peptidoglycan structure and the type of cross-linkage. Taxonomists are encouraged to study the detailed peptidoglycan structure for differentiation at the genus as well as at the species level or to seek cooperation for the respective analytical methods.

\section{Acyl type of peptidoglycan}

Although most of the genera of the suborder Micrococcineae have not yet been studied with respect to the type of acylation of the muramic acid residues in the peptidoglycan, the examination of this feature is recommended for differentiation at the genus and at the species level. Members of some genera (Microbacterium and Okibacterium) contain glycolyl (usually as well as acetyl) residues in their peptidoglycan, whereas the majority of examined genera contain only acetyl residues. The genus
Brachybacterium is inconsistent as regards the type of acylation of the muramic acid residues. Glycolylation can be detected by the procedure of Uchida \& Aida (1984) or by a miniaturized method (Uchida et al., 1999).

\section{Cell-wall sugars}

Only a few genera of the suborder Micrococcineae are consistent with respect to cell-wall sugar composition. In particular, the presence of rhamnose seems to be diagnostic for some genera. The occurrence of specific sugars in some species is desirable information in the genus description. The determination of sugars is recommended for differentiation at the species level. Since whole cells may contain incorporated sugars from the cultivation media and typically also glucose, ribose and other sugars originating from the cytoplasm or capsules, it is recommended that cell walls are isolated and purified according to Schleifer (1985) prior to the analysis. Hydrochloric acid is not suited for hydrolysis because chloro-deoxy sugars may be formed. Instead, $1 \mathrm{M}$ sulfuric acid has to be used for cell-wall hydrolysis. This can be removed easily prior to sugar analysis by extraction with $\mathrm{N}, \mathrm{N}$-dioctylmethylamine in chloroform as described by Hancock (1994). The identification of the sugars can be performed by TLC, e.g. as described by Komagata \& Suzuki (1987). Quantification of the sugars can be performed by GC or HPLC as described by Saddler $e t$ al. (1991) and Takeuchi \& Yokota (1989), respectively.

\section{Respiratory quinone patterns}

The length and degree of saturation of the isoprenoid side chain is very variable (Table 2). The structural diversity of menaquinones and demethylmenaquinones as exclusive isoprenoid quinones in the suborder Micrococcineae can be analysed quantitatively by HPLC and mass spectrometric methods (Collins, 1994).

\section{Polar lipids}

Analyses of polar lipids of bacteria are performed in most laboratories by two dimensional TLC as described by Lechevalier et al. (1977), Komagata \& Suzuki (1987) and Tindall (1990) for example. Many publications report 'unknown' phospholipid and glycolipid components (see Table 2) which could not be identified at the time of analysis. It is suggested that authors who cannot identify taxonomically relevant polar lipid components include a figure of the chromatogram in the manuscript in order to demonstrate the position of the respective spots for comparative purposes.

\section{Polyamines}

Polyamine patterns are so far available for only a limited number of genera of the suborder Micrococcineae including representatives of the families Micrococcaceae, Intrasporangiaceae, Microbacteriaceae, Sanguibacteraceae, Brevi- 
bacteraceae, Bogoriellaceae, Promicromonosporaceae, Cellulomonadaceae and Dermabacteraceae. Species of the family Micrococcaceae have been shown to exhibit polyamine patterns which consist of the predominant compound spermidine often along with significant amounts of spermine (Hamana, 1994, 1995; Altenburger et al., 1997, 2002a, 2002b; Gvozdiak et al., 1998; Busse \& Schumann, 1999; Buczolits et al., 2003; Busse et al., 2003). Higher variability in polyamine patterns was detected among genera of the family Microbacteriaceae (Altenburger et al., 1997). Members of the genera Curtobacterium, Clavibacter and Rathayibacter show polyamine patterns with the major compounds spermidine and spermine, species of the genera Agrococcus and Plantibacter are characterized by the major compound spermine and Pseudoclavibacter helvolus contains the major compounds cadaverine and 1,3-diaminopropane. The single species of the genus Leifsonia analysed, Leifsonia poae, contains the major compound putrescine. Species of the genus Agromyces are characterized by very low polyamine contents. Four species of the family Intrasporangiaceae, each representing a different genus (Intrasporangium, Terrabacter, Terracoccus and Janibacter), were shown to share putrescine as a major compound. Additional major compounds such as spermidine (Intrasporangium), spermidine and spermine (Terracoccus) or cadaverine (Janibacter) suggest the potential of polyamine patterns to distinguish at least between groups of this complex family. Species of the genera Promicromonospora and Cellulosimicrobium (family Promicromonosporaceae) as well as the genera Cellulomonas and Oerskovia (family Cellulomonadaceae) show polyamine patterns with the predominant compound spermidine and moderate amounts of spermine, but the overall polyamine concentrations may differ by two orders of magnitude. Members of the genus Brevibacterium (family Brevibacteriaceae) exhibit polyamine patterns predominated by cadaverine and putrescine and species of the genus Sanguibacter (family Sanguibacteraceae) show only spermine as the predominant polyamine. Two species of the genus Brachybacterium, representing the family Dermabacteraceae, show a polyamine pattern consisting of the major amines spermidine and spermine and the polyamine content is quite high. Georgenia muralis is the only representative of the family Bogoriellaceae which has been examined for polyamines. The major polyamines of this species are spermidine and spermine in similar concentrations, but the overall polyamine concentrations are approximately $4-12$ orders of magnitude lower than in other representatives of the suborder.

This variability among representatives of the suborder Micrococcineae indicates that polyamine patterns are conserved at distinctive taxonomic levels and are therefore recommended characteristics for classification and identification. According to available data, the following taxa or groups of genera within a family share common characteristics in polyamine patterns: Clavibacter/Rathayibacter/ Curtobacterium, Leifsonia/Agromyces, Promicromonosporal
Cellulosimicrobium, Cellulomonadaceae and Intrasporangium/ Terrabacter/Terracoccus/Janibacter. Certain polyamine patterns are found in different families but, in polyphasic classification, this approach can play an important role in distinguishing taxa which cannot be differentiated by other traits. Hence analysis of polyamine patterns can be recommended at least for those taxa listed here and data from other taxa are highly desirable to complement the classification scheme for the suborder Micrococcineae.

Polyamines can be easily extracted in less than two hours without any special equipment and analysed by gradient HPLC after derivatization with dansyl chloride and detection with a fluorescence detector (Altenburger et al., 1997; Scherer \& Kneifel, 1983) or after post-column derivatization with $o$-phthalaldehyde (Hamana, 1995).

\section{Cellular fatty acids}

The general type of cellular fatty acids (i.e. straight-chain saturated and monounsaturated type, 10-methylbranched-chain type, iso/anteiso-branched-chain type, $\omega$ cyclohexyl fatty acid type, complex type; Suzuki \& Komagata, 1983) is of significance for classification at the genus level whereas the quantitative profile of cellular fatty acids can be used for the differentiation of species. The discriminating power of cellular fatty acid profiles differs between families of the suborder Micrococcineae. For instance, most organisms of the family Microbacteriaceae display fatty acid profiles consisting of only few components of the iso- and anteiso-branched type and the discrimination of genera and species on the basis of such patterns is hardly possible. Only representatives of particular genera have been reported to contain characteristic components as $\omega$-cyclohexyl fatty acids (Suzuki \& Komagata, 1983; Qiu et al., 2007; Vaz-Moreira et al., 2008), 2-hydroxy-tetradecanoic and monounsaturated octadecenoic acid (Zhang et al., 2007b) or 1,1-dimethoxy-alkanes (Kämpfer et al., 2000; Schumann et al., 2003) (Table 2). Members of the family Intrasporangiaceae, on the other hand, are characterized by complex patterns consisting of many components which are well suited for their differentiation. As a conclusion from these observations, cellular fatty acid profiles are recommended as a minimal requirement for differentiation at the genus and at the species level. The comparison of fatty acid profiles necessitates the standardization of the cultivation conditions since the composition of media, the age of the culture, the temperature and the availability of oxygen have a strong influence on the fatty acid patterns. Therefore it may be necessary to analyse the fatty acids of strains for comparison in one and the same laboratory rather than to compare one's own data with those available from literature. This is particularly important when quantitative data on individual fatty acids rather than overall patterns are compared. The preferable method for analysis of cellular fatty acid profiles is capillary GC of fatty acid methyl esters. If it is the case that some fatty acid methyl 
esters cannot be unambiguously identified on the basis of their retention times due to co-elution (e.g. $\mathrm{C}_{18: 1} \omega 7 c$ and cyclohexyl $\mathrm{C}_{17: 0} ; 2-\mathrm{OH} \mathrm{C}_{14: 0}$ and $\mathrm{C}_{15: 0}$-DMA; $2-\mathrm{OH}$ iso$\mathrm{C}_{15: 0}$ and $\left.\mathrm{C}_{16: 1} \omega 7 c\right)$, the identification should be supported by GC/MS or hydrogenation experiments.

\section{Total protein profiles}

Whole-cell protein profiles have been proved to be useful tools for determining the coherency of species (Zlamala et al., 2002a, b) and for the differentiation of species within the genus Brachybacterium (Buczolits et al., 2003).

\section{Cell-wall teichoic acids and related anionic polymers}

Cell-wall teichoic acids have been detected in only a few genera of the suborder Micrococcineae, e.g. in Brevibacterium (Fiedler et al., 1981), Brachybacterium (Schubert et al., 1996), Agromyces (Naumova et al., 2001), Jonesia (Fiedler et al., 1984), Rarobacter (Takeuchi \& Yokota, 1989), Agromyces (Naumova et al., 2001) and in the Arthrobacter nicotianae group (Fiedler \& Schäffler, 1987). The characteristic 'presence (absence) of teichoic acids' is recommended as a useful criterion for the differentiation of relevant genera and species.

The structure and composition of cell-wall teichoic acids and other cell-wall-associated anionic polysaccharides appear to be indicative of most of the actinomycete species where such polymers have been analysed so far (e.g. Fiedler \& Schäffler, 1987; Schubert et al., 1996; Ortiz-Martinez et al., 2004; Potekhina et al., 2003a, b, 2004, 2007; Naumova et al., 2001; Shashkov et al., 2004). The structural components of these polymers (glycerol, ribitol, mannitol, erythritol, galactose, glucose, rhamnose, aminosugars etc.) have been shown to be useful for the delineation of some species, e.g. in the genera Brachybacterium (Schubert et al., 1996) and Brevibacterium (Gavrish et al., 2004) and can be recommended as phenotypic traits for the characterization and differentiation of organisms at the species level.

Cells for the analysis of anionic phosphorus-containing polymers of cell walls can be grown in any suitable liquid media supplemented with phosphorus and should be harvested at the exponential growth phase.

The simple method for detecting the cell-wall teichoic acids is the measurement of thermostable phosphate levels, e.g. by the method of Ames (1966), combined with determination of the main structural components of polymers, mainly polyols (Bergmeyer, 1974; Endl et al., 1984; Streshinskaya et al., 2002). For the isolation of anionic polymers, a native cell wall is obtained from cells by fractionated centrifugation after disruption, e.g. by ultrasonication, and purified by $2 \%$ sodium dodecyl sulfate at $100{ }^{\circ} \mathrm{C}$ for $\left.5 \mathrm{~min}\right)$. The polymers are extracted with trichloroacetic acid $\left(10 \%, 4{ }^{\circ} \mathrm{C}, 48 \mathrm{~h}\right)$. The methods for the determination of the main structural components are based on the analysis of products of acid hydrolysis $(2 \mathrm{M}$ $\mathrm{HCl}, 100{ }^{\circ} \mathrm{C}, 3 \mathrm{~h}$ ) by chemical and chromatographic methods (Archibald, 1972; Naumova et al., 1980; Takeuchi \& Yokota, 1989).

The main structural components of teichoic acids can be determined directly in the hydrolysates of purified cell walls without the extraction of polymers (Naumova et al., 1980). Polyols can also be identified by thin-layer or paper chromatography as described for sugar analysis (e.g. Komagata \& Suzuki, 1987; Becker et al., 1964), with additional staining by $5 \% \mathrm{AgNO}_{3}$ in aqueous ammonia solution (sugar spots are stained brown, while polyol spots become black). GC or HPLC analysis can also be applied (Saddler et al., 1991; Takeuchi \& Yokota, 1989).

\section{Cytochrome and haem composition}

Although cytochrome and haem patterns have been studied so far only in some genera of the suborder, including Micrococcus, Kocuria, Dermacoccus, Agreia, Plantibacter, Rathayibacter and Okibacterium, they appear to be valuable for taxonomic purposes and are recommended for the differentiation of organisms at the genus and, particularly, at the species level. The methods for testing cytochrome and haem composition are based on spectrophotometry (preliminary spectral characteristics) and chromatography (Faller et al., 1980; Trutko et al., 2003).

\section{Pigments}

Many representatives of the suborder Micrococcineae produce pigments which are typically yellow (of different tints and intensities) to orange or red. Some species of the genera Clavibacter and Arthrobacter are known to produce blue pigments. The chemical composition of pigments is not regularly determined in taxonomic studies of representatives of the suborder Micrococcineae. Nevertheless, the published data on the chemical nature and composition of pigments provide useful taxonomic information for species and subspecies characterization and differentiation as shown, for instance, in articles on the genera Brevibacterium, Clavibacter, Microbacterium and Leucobacter (Jones et al., 1973; Gavrish et al., 2004; Trutko et al., 2005; Muir \& Tan, 2007).

Most organisms analysed so far have been reported to produce carotenoids of different types and molecular masses (Dufossé et al., 2001; Krubasik \& Sadmann, 2000; Reddy et al., 2003; Trutko et al., 2005). In some species and subspecies of the genera Brevibacterium, Leifsonia, Microbacterium, Agromyces and Leucobacter chromiireducens subsp. solipictus, the carotenoid pigments are induced by light. The blue bipyridyl pigment indigoidine has been described in Clavibacter michiganensis subsp. insidiosus (Starr, 1958; Colwell et al., 1969) and some species of the genus Arthrobacter (Kuhn et al., 1965; SchippersLammertse et al., 1963; Knackmuss \& Beckman, 1973). 
The methods for the determination of pigments are based on spectrophotometry (preliminary spectral characteristics) and chromatography (Weeks, 1981; Dufossé et al., 2001; Trutko et al., 2005). While analysing pigments, it should be taken into account that growth conditions may affect their formation and that the production of pigments may be strain-dependent. Qualitative and quantitative changes in the carotenoid pigments of Curtobacterium flaccumfaciens (basonym Corynebacterium poinsettiae) were observed, for instance, when the level of the required growth factor thiamine was altered in the basal medium (Starr \& Saperstein, 1953).

\section{Fourier-transform infrared (FT-IR) spectroscopy}

The method and its taxonomic application were described in detail by Oberreuter et al. (2002). The method is particularly valuable for the differentiation of related species from similar ecological niches, which display almost identical phenotypic traits in terms of traditional physiological and biochemical criteria and similar (identical) colony colours. It should be noted that spectral similarities of strains do not necessarily correspond to their phylogenetic relationships (Kümmerle et al., 1998; Oberreuter et al., 2002). The method has been tested on many representatives of the suborder Micrococcineae (e.g. Oberreuter et al., 2002; Behrendt et al., 2002).

\section{Matrix Assisted Laser Desorption Ionization Time- of-Flight mass spectrometry (MALDI/TOF)}

MALDI/TOF mass spectrometry is a rapid and efficient identification method for intact whole bacteria (Holland $e t$ al., 1996) which has been proven to aid medical diagnostics and risk assessment. This technique may cover a broad taxonomic range depending on the instrument conditions chosen, from the genus level up to the authentication of strains. Although reports on the application of MALDI/ TOF mass spectrometry for members of the suborder Micrococcineae (Vargha et al., 2006) are still rare, this fast method has turned out to be of great taxonomic importance when compared with gene sequence phylogenies (Stackebrandt et al., 2005) and its application as a tool for characterization and differentiation at the species level is highly encouraged.

\section{GENOTYPIC CRITERIA}

\section{Analysis of the gene sequences}

$16 \mathrm{~S}$ rRNA gene sequence analysis is the current method of choice for the determination of phylogenetic relationships. The availability of the sequences of the type strains of most species with validly published names in comprehensive public databases is the main advantage of sequence analyses based on this gene. The necessity of using several different algorithms for the construction of phylogenetic dendro- grams and for the examination of the reliability of branching points has already been outlined (Bernardet et al., 2002). Whereas sequence analysis of the $23 \mathrm{~S}$ rRNA gene provides similar phylogenetic information to $16 \mathrm{~S}$ rRNA gene sequencing (Ward et al., 2000), less information should be expected from the analysis of the smaller 5S rRNA genes. Nevertheless, 5S rRNA sequencing was applied successfully for the proposal of the family Microbacteriaceae (Park et al., 1993). The degree of taxonomic resolution may be different when the phylogenetic analysis is based on other molecular targets, e.g. the DNA gyrase B subunit gene (Hatano et al., 2003; Richert et al., 2005), the tRNA intergenic spacer regions (Hinrikson et al., 2000), hrcA (Ahmad et al., 1999), hsp60 (Kwok et al., 1999), sodA (Poyart et al., 2001), rpoB (Morse et al., 2002) or tuf (Heikens et al., 2005). Though there are currently only a few complete genome sequences of members of the suborder Micrococcineae available (http:// www.genomesonline.org/), it can be expected that genome sequences will have increasing impact on the understanding of the phylogeny of the suborder Micrococcineae and in the definition of its species in future.

\section{DNA base composition}

The range of $\mathrm{G}+\mathrm{C}$ values within a genus is an important taxonomic criterion. The indication of the $\mathrm{G}+\mathrm{C}$ value of the type strain of the type species of a novel genus is mandatory; it is optional for type strains of novel species in established genera (Stackebrandt et al., 2002b). For precise determination of $\mathrm{G}+\mathrm{C}$ values, the direct quantification of nucleosides (e.g. Mesbah et al., 1989; Tamaoka \& Komagata, 1984) by HPLC methods is recommended. Since totally sequenced bacterial genomes with known base compositions have become available recently (http:// www.ncbi.nlm.nih.gov), the respective strains represent excellent reference organisms for calibration purposes.

\section{DNA-DNA hybridization}

Although there are ideas for novel promising methods for the definition of bacterial species (Stackebrandt et al., 2002b; Gevers et al., 2005), DNA-DNA hybridization is still the established technique for species delineation. Past experience has shown that DNA-DNA hybridization is recommended for the evaluation of species status when the value for 16S rRNA gene sequence similarity is above $97 \%$ (Stackebrandt \& Goebel, 1994). In order to evaluate the stringency of the DNA-DNA hybridization, it is necessary that the experimental conditions (buffer system, ionic strength and reassociation temperature) are reported. Different methods for DNA-DNA hybridization have been described and their results compared by Grimont (1988). The filter methods using radioactive DNA showed high reproducibility but lost their importance after the worldwide introduction of strict safety regulations. The reliability of results of the spectrophotometric method is comparable to those obtained by filter techniques, as revealed by the studies of Huß et al. (1983). Miniaturized methods using 
microtitre plates (e.g. Ezaki et al., 1989; Ziemke et al., 1998) offer the advantage of a higher sample throughput but can only be recommended when the reproducibility of their results is as high as those of filter or spectrophotometric techniques (Goris et al., 1998).

\section{Genomic fingerprinting}

Rapid DNA-typing methods are considered appropriate tools for the determination of inter- and intraspecies relatedness by the Ad Hoc Committee for the Re-Evaluation of the Species Definition in Bacteriology (Stackebrandt et al., 2002b). These methods investigate whole genomes (AFLP, RAPD, Rep-PCR, PFGE), rrn operons, the $16 \mathrm{~S}$ rRNA gene (ARDRA), or the intergenic 16S-23S rRNA spacer regions (ISR). Ribotyping and methods based on whole genomes are especially recommended for the examination of whether strains belong to the same species. However, it has been shown recently for Microbacterium paraoxydans that ribotyping does not identify all strains of this species (Buczolits et al., 2008), demonstrating that, as with other fingerprinting techniques, highly similar banding patterns are useful for species identification whereas different patterns do not necessarily indicate another species. However, further standardization of these techniques is required in order to improve the reproducibility between laboratories before these methods can be proposed as alternative minimal criteria that are equivalent to DNADNA hybridization. A survey of DNA fingerprinting techniques and their application in bacterial systematics is given by Pukall (2006).

\section{Sequencing of housekeeping genes and multilocus sequence typing (MLST)}

The Ad Hoc Committee for the Re-Evaluation of the Species Definition in Bacteriology (Stackebrandt et al., 2002b) considers these techniques 'methods of great promise' for novel approaches to the species concept. Information for the differentiation of species should be obtained from the sequences of at least five genes coding for proteins of metabolic function. These genes should originate from diverse chromosomal loci and occur over a wide range of taxa. Sequencing of housekeeping genes and MLST have the advantage that discrimination at the species level could be performed by comparing the sequences available from databases instead of direct comparison of isolates to type strains by DNA-DNA hybridization or DNA-typing patterns. MLST (Maiden et al., 1998) is presently mainly used in epidemiology and for the investigation of microbial populations but will have an increasing importance for bacterial systematics at the interand intraspecific level (Stackebrandt, 2002).

\section{NOTE ADDED IN PROOF}

The genus name Frondicola Zhang et al. 2007 was recently deemed to be illegitimate as it is a later homonym of a fungal genus name Frondicola Hyde, 1992 (Fungi, Ascomycota, Sordariomycetes, Xylariomycetidae, Xylariales, Hyponectriaceae) [Principle 2 and Rule 51b(4) of the Bacteriological Code (1990 Revision)]. Therefore, a new genus name, Frondihabitans gen. nov., has been proposed for this taxon (Greene et al., 2009). A new name was proposed for the type species, Frondihabitans australicus sp. nov., to replace the illegitimate combination Frondicola australicus Zhang et al. 2007.

\section{ACKNOWLEDGEMENTS}

This paper is dedicated to Erko Stackebrandt as an author of the suborder Micrococcineae and a former active member of the Subcommittee on the Taxonomy of the Suborder Micrococcineae, on the occasion of his 65th birthday. The authors are grateful to him and all other members of the Subcommittee on the Taxonomy of the Suborder Micrococcineae of the International Committee on Systematics of Prokaryotes for their input, stimulating discussions and careful reading of the manuscript: O. R. Gvozdyak (Billerica, USA), S. D. Lee (Jeju National University, Jeju, Republic of Korea), W. J. Li (Yunnan University, Kunming, China), K. Suzuki (Biological Resource Center NBRC, Chiba, Japan), R. Pukall, (DSMZ-German Collection of Microorganisms and Cell Cultures, Braunschweig, Germany), E. M. Tóth (Eötvös Lórand University, Budapest, Hungary) and A. Yokota (University of Tokyo, Tokyo, Japan). The authors are also indebted to Wolfgang Ludwig (Technical University of Munich, Freising, Germany) for valuable discussions on the phylogenetic structure of the suborder Micrococcineae.

\section{REFERENCES}

Ahmad, S., Selvapandiyan, A. \& Bhatnagar, R. (1999). A proteinbased phylogenetic tree for Gram-positive bacteria derived from $h r c A$, a unique heat-shock regulatory gene. Int J Syst Bacteriol 49, 13871394.

Altenburger, P., Kämpfer, P., Akimov, V. N., Lubitz, W. \& Busse, H. J. (1997). Polyamine distribution in actinomycetes with group $B$ peptidoglycan and species of the genera Brevibacterium, Corynebacterium and Tsukamurella. Int J Syst Bacteriol 47, 270-277.

Altenburger, P., Kämpfer, P., Schumann, P., Steiner, R., Lubitz, W. \& Busse, H. J. (2002a). Citricoccus muralis gen. nov., sp. nov., a novel actinobacterium isolated from a medieval wall painting. Int J Syst Evol Microbiol 52, 2095-2100.

Altenburger, P., Kämpfer, P., Schumann, P., Vybiral, D., Lubitz, W. \& Busse, H. J. (2002b). Georgenia muralis gen. nov., sp. nov., a novel actinobacterium isolated from a medieval wall painting. Int J Syst Evol Microbiol 52, 875-881.

Ames, B. N. (1966). Assay of inorganic phosphate, total phosphate and phosphatase. Methods Enzymol 8, 115-118.

An, S.-Y., Xiao, T. \& Yokota, A. (2008). Schumannella luteola gen. nov., sp. nov., a novel genus of the family Microbacteriaceae. J Gen Appl Microbiol 54, 253-258.

Archibald, A. R. (1972). Teichoic acids. In General Carbohydrate Methods, Methods in Carbohydrate Chemistry, vol. 6, pp. 162-172. Edited by R. L. Whistler \& J. N. BeMiller. London: Academic Press.

Austwick, P. K. C. (1958). Cutaneous streptotrichosis, mycotic dermatitis and strawberry foot root and the genus Dermatophilus Van Saceghem. Vet Rev Annot 4, 33-38.

Bakalidou, A., Kämpfer, P., Berchtold, M., Kuhnigk, T., Wenzel, M. \& König, H. (2002). Cellulosimicrobium variabile sp. nov., a cellulolytic 
bacterium from the hindgut of the termite Mastotermes darwiniensis. Int J Syst Evol Microbiol 52, 1185-1192.

Barrow, G. I. \& Feltham, R. K. A. (1993). Cowan and Steel's Manual for the Identification of Medical Bacteria, 3rd edn. Cambridge: Cambridge University Press.

Becker, B., Lechevalier, M. P., Gordon, R. E. \& Lechevalier, H. A. (1964). Rapid differentiation between Nocardia and Streptomyces by paper chromatography of whole cell hydrolysates. Appl Microbiol 12, 421-423.

Behrendt, U., Ulrich, A., Schumann, P., Naumann, D. \& Suzuki, K. (2002). Diversity of grass-associated Microbacteriaceae isolated from the phyllosphere and litter layer after mulching the sward; polyphasic characterization of Subtercola pratensis sp. nov., Curtobacterium herbarum sp. nov. and Plantibacter flavus gen. nov., sp. nov. Int J Syst Evol Microbiol 52, 1441-1454.

Bergan, T. \& Kocur, M. (1982). Stomatococcus mucilaginosus gen. nov., sp. nov., ep. rev., a member of the family Micrococcaceae. Int J Syst Bacteriol 32, 374-377.

Bergey, D. H., Harrison, F. C., Breed, R. S., Hammer, B. W. \& Huntoon, F. M. (1923). Bergey's Manual of Determinative Bacteriology. Baltimore, MD: Williams \& Wilkins.

Bergmeyer, H. U. (1974). Methoden der Enzymatischen Analyse. Weinheim: Verlag Chemie (in German).

Bernardet, J. F., Nakagawa, Y. \& Holmes, B. (2002). Proposed minimal standards for describing new taxa of the family Flavobacteriaceae and emended description of the family. Int J Syst Evol Microbiol 52, 1049-1070.

Breed, R. S. (1953). The families developed from Bacteriaceae Cohn with a description of the family Brevibacteriaceae. Riass Commun VI Congr Int Microbiol Roma 1, 10-15.

Brown, J. M., Steigerwalt, A. G., Morey, R. E., Daneshvar, M. I., Romero, L. J. \& McNeil, M. M. (2006). Characterization of clinical isolates previously identified as Oerskovia turbata: proposal of Cellulosimicrobium funkei sp. nov. and emended description of the genus Cellulosimicrobium. Int J Syst Evol Microbiol 56, 801-804.

Buczolits, S., Schumann, P., Weidler, G., Radax, C. \& Busse, H.-J. (2003). Brachybacterium muris sp. nov., isolated from the liver of a laboratory mouse strain. Int J Syst Evol Microbiol 53, 1955-1960.

Buczolits, S., Schumann, P., Valens, M., Rosselló-Mora, R. \& Busse, H.-J. (2008). Identification of a bacterial strain isolated from the liver of a laboratory mouse as Microbacterium paraoxydans and emended description of the species Microbacterium paraoxydans Laffineur et al. 2003. Indian J Microbiol 48, 243-251.

Busse, H. J. \& Schumann, P. (1999). Polyamine profiles within genera of the class Actinobacteria with LL-diaminopimelic acid in the peptidoglycan. Int J Syst Bacteriol 49, 179-184.

Busse, H.-J., Zlamala, C., Buczolits, S., Lubitz, W., Kämpfer, P. \& Takeuchi, M. (2003). Promicromonospora vindobonensis sp. nov. and Promicromonospora aerolata sp. nov., isolated from the air in the medieval 'Virgilkapelle' in Vienna. Int J Syst Evol Microbiol 53, 1503 1507.

Cazemier, A. E., Verdoes, J. C., Reubsaet, F. A. G., Hackstein, J. H. P., van der Drift, C. \& Op den Camp, H. J. M. (2003). Promicromonospora pachnodae sp. nov., a member of the (hemi)cellulolytic hindgut flora of larvae of the scarab beetle Pachnoda marginata. Antonie van Leeuwenhoek 83, 135-148.

Cazemier, A. E., Verdoes, J. C., Reubsaet, F. A. G., Hackstein, J. H. P., van der Drift, C. \& Op den Camp, H. J. M. (2004). Promicromonospora pachnodae sp. nov. In Validation of the Publication of New Names and New Combinations Previously Effectively Published Outside the IJSEM, List no. 95. Int J Syst Evol Microbiol 54, 1-2.
Christensen, W. B. (1946). Urea decomposition as a means of differentiating Proteus and paracolon cultures from each other and from Salmonella and Shigella types. J Bacteriol 52, 461-466.

Cohn, F. (1872). Untersuchungen über Bakterien. Beitr Biol Pflanz 1, 127-224 (in German).

Collins, M. D. (1994). Isoprenoid quinones. In Chemical Methods in Prokaryotic Systematics, pp. 265-309. Edited by M. Goodfellow \& A. G. O’Donnell. Chichester: John Wiley \& Sons Ltd.

Collins, M. D., Jones, D., Keddie, R. M., Kroppenstedt, R. M. \& Schleifer, K. H. (1983). Classification of some coryneform bacteria in a new genus Aureobacterium. Syst Appl Microbiol 4, 236-252.

Collins, M. D., Brown, J. \& Jones, D. (1988). Brachybacterium faecium gen. nov., sp. nov., a coryneform bacterium from poultry deep litter. Int J Syst Bacteriol 38, 45-48.

Collins, M. D., Dorsch, M. \& Stackebrandt, E. (1989). Transfer of Pimelobacter tumescens to Terrabacter gen. nov. as Terrabacter tumescens comb. nov. and of Pimelobacter jensenii to Nocardioides as Nocardioides jensenii comb. nov. Int J Syst Bacteriol 39, 1-6.

Collins, M. D., Hutson, R. A., Baverud, V. \& Falsen, E. (2000). Characterization of a Rothia-like organism from a mouse: description of Rothia nasimurium sp. nov. and reclassification of Stomatococcus mucilaginosus as Rothia mucilaginosa comb. nov. Int J Syst Evol Microbiol 50, 1247-1251.

Collins, M. D., Lawson, P. A., Labrenz, M., Tindall, B. J., Weiss, N. \& Hirsch, P. (2002). Nesterenkonia lacusekhoensis sp. nov., isolated from hypersaline Ekho Lake, East Antarctica, and emended description of the genus Nesterenkonia. Int J Syst Evol Microbiol 52, 1145-1150.

Collins, M. D., Routh, J., Saraswathy, A., Lawson, P. A., Schumann, P., Welinder-Olsson, C. \& Falsen, E. (2004). Arsenicicoccus bolidensis gen. nov., sp. nov., a novel actinomycete isolated from contaminated lake sediment. Int J Syst Evol Microbiol 54, 605-608.

Colwell, R. R., Citarella, R. V., Ryman, I. \& Chapman, G. B. (1969). Properties of Pseudomonas iodinum. Can J Microbiol 15, 851-857.

Conn, H. J. (1928). A type of bacteria abundant in productive soils, but apparently lacking in certain soils of low productivity. NY Agric Exp Stn Geneva Bull 138, 3-26.

Conn, H. J. \& Dimmick, I. (1947). Soil bacteria similar in morphology to Mycobacterium and Corynebacterium. J Bacteriol 54, 291-303.

Cook, D. M., Henriksen, E. D., Rogers, T. E. \& Peterson, J. D. (2008). Klugiella xanthotipulae gen. nov., sp. nov., a novel member of the family Microbacteriaceae. Int J Syst Evol Microbiol 58, 2779-2782.

Cui, X., Schumann, P., Stackebrandt, E., Kroppenstedt, R. M., Pukall, R., Xu, L., Rohde, M. \& Jiang, C. (2004). Myceligenerans xiligouense gen. nov., sp. nov., a novel hyphae-forming member of the family Promicromonosporaceae. Int J Syst Evol Microbiol 54, 1287-1293.

Davis, M. J., Gillaspie, A. G., Jr, Vidaver, A. K. \& Harris, R. W. (1984). Clavibacter: a new genus containing some phytopathogenic coryneform bacteria, including Clavibacter xyli subsp. xyli sp. nov., subsp. nov. and Clavibacter xyli subsp. cynodontis subsp. nov., pathogens that cause ratoon stunting disease of sugarcane and Bermudagrass stunting disease. Int J Syst Bacteriol 34, 107-117.

Dufossé, L., Mahon, P. \& Binet, A. (2001). Assessment of the coloring strength of Brevibacterium linens strains: spectrocolorimetry versus total carotenoid extraction/quantification. J Dairy Sci 84, 354-360.

Endl, J., Seidl, P. H., Fiedler, F. \& Schleifer, K. H. (1984). Determination of cell wall teichoic acid structure of staphylococci by rapid chemical and serological screening methods. Arch Microbiol 137, 272-280.

Erikson, D. (1954). Factors promoting cell division in a 'soft' mycelial type of Nocardia: Nocardia turbata n. sp. J Gen Microbiol 11, 198-208. 
Evtushenko, L. I., Dorofeeva, L. V., Subbotin, S. A., Cole, J. R. \& Tiedje, J. M. (2000). Leifsonia poae gen. nov., sp. nov., isolated from nematode galls on Poa annua, and reclassification of 'Corynebacterium aquaticum' Leifson 1962 as Leifsonia aquatica (ex Leifson 1962) gen. nov., nom. rev., comb. nov. and Clavibacter xyli Davis et al. 1984 with two subspecies as Leifsonia xyli (Davis et al. 1984) gen. nov., comb. nov. Int J Syst Evol Microbiol 50, 371-380.

Evtushenko, L. I., Dorofeeva, L., Dobrovolskaya, T., Streshinskaya, G., Subbotin, S. \& Tiedje, J. (2001). Agreia bicolorata gen. nov., sp. nov., to accommodate actinobacteria isolated from narrow reed grass infected by the nematode Heteroanguina graminophila. Int J Syst Evol Microbiol 51, 2073-2079.

Evtushenko, L. I., Dorofeeva, L. V., Krausova, V. I., Gavrish, E. Y., Yashina, S. G. \& Takeuchi, M. (2002). Okibacterium fritillariae gen. nov., sp. nov., a novel genus of the family Microbacteriaceae. Int J Syst Evol Microbiol 52, 987-993.

Ezaki, T., Hashimoto, Y. \& Yabuuchi, E. (1989). Fluorometric deoxyribonucleic acid-deoxyribonucleic acid hybridization in microdilution wells as an alternative to membrane filter hybridization in which radioisotopes are used to determine genetic relatedness among bacterial strains. Int J Syst Bacteriol 39, 224-229.

Faller, A., Gotz, F. \& Schleifer, K. H. (1980). Cytochrome patterns of staphylococci and micrococci and their taxonomic implications. Zentralbl Bakteriol Parasitenkd Infektionskr Hyg Abt 1 Orig Reihe C 1, 26-39.

Fernandez-Garayzabal, J. F., Dominguez, L., Pascual, C., Jones, D. \& Collins, M. D. (1995). Phenotypic and phylogenetic characterization of some unknown coryneform bacteria isolated from bovine blood and milk: description of Sanguibacter gen. nov. Lett Appl Microbiol 20, 69-75.

Fiedler, F. \& Schäffler, M. J. (1987). Teichoic acids in cell walls of strains of the 'nicotianae' group of Arthrobacter: a chemotaxonomic marker. Syst Appl Microbiol 9, 16-21.

Fiedler, F., Schäffler, M. J. \& Stackebrandt, E. (1981). Biochemical and nucleic acid hybridisation studies on Brevibacterium linens and related strains. Arch Microbiol 129, 85-93.

Fiedler, F., Seger, J., Schrettenbrunner, A. \& Seeliger, H. P. R. (1984). The biochemistry of murein and cell wall teichoic acids in the genus Listeria. Syst Appl Microbiol 5, 360-376.

Flügge, C. (1886). Die Mikroorganismen. Leipzig: Vogel, F. C. W. (in German).

Frank, H., Rettenmeier, A., Weicker, H., Nicholson, G. J. \& Bayer, E. (1980). A new gas chromatographic method for determination of amino acid levels in human serum. Clin Chim Acta 105, 201-211.

Gavrish, E. Y., Krauzova, V. I., Potekhina, N. V., Karasev, S. G., Plotnikova, E. G., Altyntseva, O. V., Korosteleva, L. A. \& Evtushenko, L. I. (2004). Three new species of brevibacteria, Brevibacterium antiquum sp. nov., Brevibacterium aurantiacum sp. nov., and Brevibacterium permense sp. nov. Microbiology (English translation of Mikrobiologiia) 73, 176-183.

Georg, L. K. \& Brown, J. M. (1967). Rothia gen. nov., an aerobic genus of the family Actinomycetaceae. Int J Syst Bacteriol 17, 79-88.

Gevers, D., Cohan, F. M., Lawrence, J. G., Spratt, B. G., Coenye, T., Feil, E. J., Stackebrandt, E., de Peer, Y. V., Vandamme, P. \& other authors (2005). Re-evaluating prokaryotic species. Nat Rev Microbiol 3, 733-739.

Gledhill, W. E. \& Casida, L. E., Jr (1969). Predominant catalase-negative soil bacteria. III. Agromyces, gen. n., microorganisms intermediary to Actinomyces and Nocardia. Appl Microbiol 18, 340-349.

Gordon, M. A. (1964). The genus Dermatophilus. J Bacteriol 88, 509522.

Gordon, R. E. \& Mihm, J. M. (1957). A comparative study of some strains received as nocardiae. J Bacteriol 73, 15-27.
Goris, J., Suzuki, K., De Vos, P., Nakase, T. \& Kersters, K. (1998). Evaluation of a microplate DNA-DNA hybridization method compared with the initial renaturation method. Can J Microbiol 44, 1148-1153.

Greene, A. G., Euzéby, J. P., Tindall, B. J. \& Patel, B. K. C. (2009). Proposal of Frondihabitans gen. nov. to replace the illegitimate genus name Frondicola Zhang et al. 2007. Int J Syst Evol Microbiol 59, 447-448.

Grimont, P. A. D. (1988). Use of DNA reassociation in bacterial classification. Can J Microbiol 34, 541-546.

Groth, I., Schumann, P., Weiss, N., Martin, K. \& Rainey, F. A. (1996). Agrococcus jenensis gen. nov., sp. nov., a new genus of actinomycetes with diaminobutyric acid in the cell wall. Int J Syst Bacteriol 46, 234-239.

Groth, I., Schumann, P., Rainey, F. A., Martin, K., Schütze, B. \& Augsten, K. (1997a). Bogoriella caseilytica gen. nov., sp. nov., a new alkaliphilic actinomycete from a soda lake in Africa. Int J Syst Bacteriol 47, 788-794.

Groth, I., Schumann, P., Rainey, F. A., Martin, K., Schütze, B. \& Augsten, K. (1997b). Demetria terragena gen. nov., sp. nov., a new genus of actinomycetes isolated from compost soil. Int J Syst Bacteriol 47, 1129-1133.

Groth, I., Schumann, P., Martin, K., Schütze, B., Augsten, K., Kramer, I. \& Stackebrandt, E. (1999a). Ornithinicoccus hortensis gen. nov., sp. nov., a soil actinomycete which contains L-ornithine. Int J Syst Bacteriol 49, 1717-1724.

Groth, I., Schumann, P., Schütze, B., Augsten, K., Kramer, I. \& Stackebrandt, E. (1999b). Beutenbergia cavernae gen. nov., sp. nov., an L-lysine-containing actinomycete isolated from a cave. Int J Syst Bacteriol 49, 1733-1740.

Groth, I., Schumann, P., Weiss, N., Schütze, B., Augsten, K. \& Stackebrandt, E. (2001). Ornithinimicrobium humiphilum gen. nov., sp. nov., a novel soil actinomycete with L-ornithine in the peptidoglycan. Int J Syst Evol Microbiol 51, 81-87.

Groth, I., Schumann, P., Schütze, B., Augsten, K. \& Stackebrandt, E. (2002). Knoellia sinensis gen. nov., sp. nov. and Knoellia subterranea sp. nov., two novel actinobacteria isolated from a cave. Int J Syst Evol Microbiol 52, 77-84.

Gu, Q., Pasciak, M., Luo, H., Gamian, A., Liu, Z. \& Huang, Y. (2007). Ruania albidiflava gen. nov., sp. nov., a novel member of the suborder Micrococcineae. Int J Syst Evol Microbiol 57, 809-814.

Gvozdiak, O. R., Schumann, P., Griepenburg, U. \& Auling, G. (1998). Polyamine profiles of Gram-positive catalase positive cocci. Syst Appl Microbiol 21, 279-284.

Hamana, K. (1994). Polyamine distribution patterns in aerobic Grampositive cocci and some radio-resistant bacteria. J Gen Appl Microbiol 40, 181-195.

Hamana, K. (1995). Polyamine distribution patterns in coryneform bacteria and related Gram-positive eubacteria. Annu Rep Coll Med Care Technol Gunma Univ 16, 69-77.

Han, S. K., Nedashkovskaya, O. I., Mikhailov, V. V., Kim, S. B. \& Bae, K. S. (2003). Salinibacterium amurskyense gen. nov., sp. nov., a novel genus of the family Microbacteriaceae from the marine environment. Int J Syst Evol Microbiol 53, 2061-2066.

Hancock, I. C. (1994). Analysis of cell wall constituents of Grampositive bacteria. In Chemical Methods in Prokaryotic Systematics, pp. 63-84. Edited by M. Goodfellow \& A. G. O’Donnell. Chichester: John Wiley \& Sons Ltd.

Hatano, K., Nishii, T. \& Kasai, H. (2003). Taxonomic re-evaluation of whorl-forming Streptomyces (formerly Streptoverticillium) species by using phenotypes, DNA-DNA hybridization and sequences of $g y r B$, and proposal of Streptomyces luteireticuli (ex Katoh and Arai 1957) corrig., sp. nov., nom. rev. Int J Syst Evol Microbiol 53, 1519-1529. 
Heikens, E., Fleer, A., Paauw, A., Florijn, A. \& Fluit, A. C. (2005). Comparison of genotypic and phenotypic methods for species-level identification of clinical isolates of coagulase-negative staphylococci. J Clin Microbiol 43, 2286-2290.

Hinrikson, H. P., Dutly, F. \& Altwegg, M. (2000). Analysis of the actinobacterial insertion in domain III of the 23S rRNA gene of uncultured variants of the bacterium associated with Whipple's disease using broad-range and 'Tropheryma whippelii'-specific PCR. Int J Syst Evol Microbiol 50, 1007-1011.

Holland, R. D., Wikes, J. G., Rafii, F., Sutherland, J. B., Persons, C. C., Voorhees, K. J. \& Lay, J. O. J. (1996). Rapid identification of intact whole bacteria based on spectral patterns using matrix-assisted laser desorption/ionization with time-of-flight mass spectrometry. Rapid Commun Mass Spectrom 10, 1227-1232.

Holt, J. G. \& Krieg, N. R. (1994). Enrichment and isolation. In Methods for General and Molecular Bacteriology, pp. 179-215. Edited by P. Gerhart, R. G. E. Murray, W. A. Wood \& N. R. Krieg. Washington, DC: American Society for Microbiology.

Huß, V. A. R., Festl, H. \& Schleifer, K. H. (1983). Studies on the spectrophotometric determination of DNA hybridization from renaturation rates. Syst Appl Microbiol 4, 184-192.

Inoue, K. \& Komagata, K. (1976). Taxonomic study on obligately psychrophilic bacteria isolated from Antarctica. J Gen Appl Microbiol 22, 165-176.

Ishikawa, T. \& Yokota, A. (2006). Reclassification of Arthrobacter duodecadis Lochhead 1958 as Tetrasphaera duodecadis comb. nov. and emended description of the genus Tetrasphaera. Int J Syst Evol Microbiol 56, 1369-1373.

Jensen, H. L. (1934). Studies on saprophytic mycobacteria and corynebacteria. Proc Linn Soc N S W 59, 19-61.

Jones, D. \& Collins, M. D. (1988). Taxonomic studies on some human cutaneous coryneform bacteria: Description of Dermabacter hominis gen. nov., sp. nov. FEMS Microbiol Lett 51, 51-55.

Jones, D., Watkins, J. \& Erikson, S. K. (1973). Taxonomically significant color changes in Brevibacterium linens probably associated with a carotenoid-like pigment. J Gen Microbiol 77, 145-150.

Jung, S. Y., Kim, H. S., Song, J. J., Lee, S. G., Oh, T. K. \& Yoon, J. H. (2006). Kribbia dieselivorans gen. nov., sp. nov., a novel member of the family Intrasporangiaceae. Int J Syst Evol Microbiol 56, 2427-2432.

Kageyama, A., Takahashi, Y., Seki, T., Tomoda, H. \& Omura, S. (2005). Oryzihumus leptocrescens gen. nov., sp. nov. Int J Syst Evol Microbiol 55, 2555-2559.

Kageyama, A., Takahashi, Y. \& Omura, S. (2007). Humihabitans oryzae gen. nov., sp. nov. Int J Syst Evol Microbiol 57, 2163-2166.

Kageyama, A., Haga, T., Kasai, H., Shizuri, Y., Omura, S. \& Takahashi, Y. (2008a). Marihabitans asiaticus gen. nov., sp. nov., a meso-diaminopimelic acid containing member of the family Intrasporangiaceae. Int J Syst Evol Microbiol 58, 2429-2432.

Kageyama, A., Matsumoto, A., Omura, S. \& Takahashi, Y. (2008b). Humibacillus xanthopallidus gen. nov., sp. nov. Int J Syst Evol Microbiol 58, 1547-1551.

Kalakoutskii, L. V., Kirillova, I. P. \& Krassil'nikov, N. A. (1967). A new genus of the Actinomycetales, Intrasporangium gen. nov. J Gen Microbiol 48, 79-85.

Kämpfer, P., Rainey, F., Andersson, M., Nurmiaho Lassila, L., Ulrych, U., Busse, H., Weiss, N., Mikkola, R. \& Salkinoja-Salonen, M. (2000). Frigoribacterium faeni gen. nov., sp. nov., a novel psychrophilic genus of the family Microbacteriaceae. Int J Syst Evol Microbiol 50, 355-363.

Katayama, T., Kato, T., Tanaka, M., Douglas, T. A., Brouchkov, A., Fukuda, M., Tomita, F. \& Asano, K. (2009). Glaciibacter superstes gen. nov., sp. nov., a novel member of the family Microbacteriaceae isolated from a permafrost ice wedge. Int J Syst Evol Microbiol 59, $482-486$.

Kellerman, F. K. \& McBeth, I. G. (1912). The fermentation of cellulose. Zentralbl Bakteriol Parasitenkd Infektionskr Hyg Abt II 34, 485-494.

Knackmuss, H. J. \& Beckman, W. (1973). The structure of nicotine blue from Arthrobacter oxydans. Arch Mikrobacteriol 90, 167-169.

Koch, C., Schumann, P. \& Stackebrandt, E. (1995). Reclassification of Micrococcus agilis (Ali-Cohen 1889) to the genus Arthrobacter as Arthrobacter agilis comb. nov. and emendation of the genus Arthrobacter. Int J Syst Bacteriol 45, 837-839.

Komagata, K. \& lizuka, H. (1964). New species of Brevibacterium isolated from rice. (Studies on the microorganisms of cereal grains, Part VII). J Agric Chem Soc Japan 38, 496-502.

Komagata, K. \& Suzuki, K. I. (1987). Lipid and cell-wall analysis in bacterial systematics. Methods Microbiol 19, 161-207.

Koyama, Y., Yazawa, Y., Yamagishi, S. \& Arai, T. (1974). Photochromogensis. I. Photochromogenicity in genus Nocardia, Corynebacterium, Arthrobacter, Brevibacterium, and Flavobacterium. Jpn J Microbiol 18, 49-56.

Krassil'nikov, N. A., Kalakoutskii, L. V. \& Kirillova, N. F. (1961). A new genus of ray fungi - Promicromonospora gen. nov. Izv Akad Nauk SSSR (Ser Biol) 1, 107-112.

Krubasik, P. \& Sadmann, G. (2000). A carotenogenic gene cluster from Brevibacterium linens with novel lycopene cyclase genes involved in the synthesis of aromatic carotenoids. Mol Gen Genet 263, 423-432.

Kuhn, R., Starr, M. P., Kuhn, D. A., Bauer, H. \& Knackmuss, H. J. (1965). Indigoidine and other bacterial pigments related to $3,3^{\prime}$ bipyridyl. Arch Mikrobiol 51, 71-84.

Kümmerle, M., Scherer, S. \& Seiler, H. (1998). Rapid and reliable identification of fermentative yeasts by Fourier-transform infrared spectroscopy. Appl Environ Microbiol 64, 2207-2214.

Kwok, A. Y., Su, S., Reynolds, R., Bay, S., Av-Gay, Y., Dovichi, N. \& Chow, A. (1999). Species identification and phylogenetic relationships based on partial HSP60 gene sequences within the genus Staphylococcus. Int J Syst Bacteriol 49, 1181-1192.

Labeda, D. P. (1997). International Committee on Systematic Bacteriology VIIth International Congress of Microbiology and Applied Bacteriology, Minutes of the meetings, 17, 18 and 22 August 1996, Jerusalem, Israel. Int J Syst Bacteriol 47, 597-600.

Labeda, D. P. (2000). International Committee on Systematic Bacteriology IXth International (IUMS) Congress of Bacteriology and Applied Microbiology, Minutes of the meetings, 14 and 17 August 1999, Sydney, Australia. Int J Syst Evol Microbiol 50, 2245-2247.

Lapage, S. P., Sneath, P. H. A., Lessel, E. F., Skerman, V. B. D., Seeliger, H. P. R. \& Clark, W. A. (editors) (1992). International Code of Nomenclature of Bacteria (1990 revision). Washington DC: American Society for Microbiology.

La Scola, B., Fenollar, F., Fournier, P., Altwegg, M., Mallet, M. \& Raoult, D. (2001). Description of Tropheryma whipplei gen. nov., sp. nov., the Whipple's disease bacillus. Int J Syst Evol Microbiol 51, 14711479.

Lechevalier, M. P., De Bièvre, C. \& Lechevalier, H. P. (1977). Chemotaxonomy of aerobic actinomycetes: phospholipid composition. Biochem Syst Ecol 5, 249-260.

Lee, S. D. (2006). Phycicoccus jejuensis gen. nov., sp. nov., an actinomycete isolated from seaweed. Int J Syst Evol Microbiol 56, 2369-2373.

Lee, S. D. (2007). Labedella gwakjiensis gen. nov., sp. nov., a novel actinomycete of the family Microbacteriaceae. Int J Syst Evol Microbiol 57, 2498-2502. 
Lee, S. D. \& Lee, D. W. (2007). Lapillicoccus jejuensis gen. nov., sp. nov., a novel actinobacterium of the family Intrasporangiaceae, isolated from stone. Int J Syst Evol Microbiol 57, 2794-2798.

Lee, D. W., Lee, J. M., Seo, J. P., Schumann, P., Kim, S. J. \& Lee, S. D. (2008). Phycicola gilvus gen. nov., sp. nov., an actinobacterium isolated from living seaweed. Int J Syst Evol Microbiol 58, 1318-1323.

Leifson, E. (1962). The bacterial flora of distilled and stored water. III: New species of the genera Corynebacterium, Flavobacterium, Spirillum and Pseudomonas. Int Bull Bacteriol Nomencl Taxon 12, 161-170.

Li, W. J., Chen, H. H., Xu, P., Zhang, Y. Q., Schumann, P., Tang, S. K., Xu, L. H. \& Jiang, C. L. (2004). Yania halotolerans gen. nov., sp. nov., a novel member of the suborder Micrococcineae from saline soil in China. Int J Syst Evol Microbiol 54, 525-531.

Li, W.-J., Schumann, P., Zhang, Y.-Q., Xu, P., Chen, G.-Z., Xu, L.-H., Stackebrandt, E. \& Jiang, C.-L. (2005). Proposal of Yaniaceae fam. nov. and Yania flava sp. nov. and emended description of the genus Yania. Int J Syst Evol Microbiol 55, 1933-1938.

Li, W.-J., Xu, P., Schumann, P., Zhang, Y.-O., Pukall, R., Xu, L.-H., Stackebrandt, E. \& Jiang, C.-L. (2007). Georgenia ruanii sp. nov., a novel actinobacterium isolated from forest soil in Yunnan (China), and emended description of the genus Georgenia. Int J Syst Evol Microbiol 57, 1424-1428.

Li, W. J., Zhi, X. Y. \& Euzéby, J. P. (2008). Proposal of Yaniellaceae fam. nov., Yaniella gen. nov. and Sinobaca gen. nov. as replacements for the illegitimate prokaryotic names Yaniaceae Li et al. 2005, Yania Li et al. 2004, emend $\mathrm{Li}$ et al. 2005, and Sinococcus Li et al. 2006, respectively. Int J Syst Evol Microbiol 58, 525-527.

Lin, Y.-C., Uemori, K., de Briel, D. A., Arunpairojana, V. \& Yokota, A. (2004). Zimmermannella helvola gen. nov., sp. nov., Zimmermannella alba sp. nov., Zimmermannella bifida sp. nov., Zimmermannella faecalis sp. nov. and Leucobacter albus sp. nov., novel members of the family Microbacteriaceae. Int J Syst Evol Microbiol 54, 1669-1676.

Liu, W. T., Hanada, S., Marsh, T. L., Kamagata, Y. \& Nakamura, K. (2002). Kineosphaera limosa gen. nov., sp. nov., a novel Gram-positive polyhydroxyalkanoate-accumulating coccus isolated from activated sludge. Int J Syst Evol Microbiol 52, 1845-1849.

MacKenzie, S. L. (1984). Amino acids and peptides. In Gas Chromatography/Mass Spectrometry Applications in Microbiology, pp. 157-204. Edited by G. Odham, L. Larsson \& P. Mardh: Plenum Publishing Corporation.

MacKenzie, S. L. (1987). Gas chromatographic analysis of amino acids as the $N$-heptafluorobutyryl isobutyl esters. J Assoc Off Anal Chem 70, 151-160.

Maiden, M. C. J., Bygraves, J. A., Feil, E., Morelli, G., Russell, J. E., Urwin, R., Zhang, Q., Zhou, J., Zurth, K. \& other authors (1998). Multilocus sequence typing: a portable approach to the identification of clones within populations of pathogenic microorganisms. Proc Natl Acad Sci U S A 95, 3140-3145.

Manaia, C. M., Nogales, B., Weiss, N. \& Nunes, O. C. (2004). Gulosibacter molinativorax gen. nov., sp. nov., a molinate-degrading bacterium, and classification of 'Brevibacterium helvolum' DSM 20419 as Pseudoclavibacter helvolus gen. nov., sp. nov. Int J Syst Evol Microbiol 54, 783-789.

Männistö, M. K., Schumann, P., Rainey, F. A., Kämpfer, P., Tsitko, I., Tiirola, M. A. \& Salkinoja-Salonen, M. S. (2000). Subtercola boreus gen. nov., sp. nov. and Subtercola frigoramans sp. nov., two new psychrophilic actinobacteria isolated from boreal groundwater. Int $J$ Syst Evol Microbiol 50, 1731-1739.

Martel, A., Pasmans, F., Hellebuyck, T., Haesebrouck, F. \& Vandamme, P. (2008). Devriesea agamarum gen. nov., sp. nov., a novel actinobacterium associated with dermatitis and septicaemia in agamid lizards. Int J Syst Evol Microbiol 58, 2206-2209.
Martin, K., Schumann, P., Rainey, F. A., Schütze, B. \& Groth, I. (1997). Janibacter limosus gen. nov., sp. nov., a new actinomycete with mesodiaminopimelic acid in the cell wall. Int J Syst Bacteriol 47, 529-534.

Maszenan, A. M., Seviour, R. J., Patel, B. K. C., Schumann, P., Burghardt, J., Tokiwa, Y. \& Stratton, H. M. (2000). Three isolates of novel polyphosphate-accumulating Gram-positive cocci, obtained from activated sludge, belong to a new genus, Tetrasphaera gen. nov., and description of two new species, Tetrasphaera japonica sp. nov. and Tetrasphaera australiensis sp. nov. Int J Syst Evol Microbiol 50, 593-603.

Matsumoto, A., Yamada, M., Omura, S. \& Takahashi, Y. (2008). Microterricola viridarii gen. nov., sp. nov., a new member of the family Microbacteriaceae. Int J Syst Evol Microbiol 58, 1019-1023.

Mesbah, M., Premachandran, U. \& Whitman, W. B. (1989). Precise measurement of the $\mathrm{G}+\mathrm{C}$ content of deoxyribonucleic acid by highperformance liquid chromatography. Int J Syst Bacteriol 39, 159-167.

Metcalfe, G. \& Brown, M. E. (1957). Nitrogen fixation by new species of Nocardia. J Gen Microbiol 17, 567-572.

Møller, V. (1955). Simplified tests for some amino acid decarboxylases and for the arginine dihydrolase system. Acta Pathol Microbiol Scand 36, 158-172.

Morse, R., O’Hanlon, K. \& Collins, M. D. (2002). Phylogenetic, amino acid content and indel analyses of the beta subunit of DNAdependent RNA polymerase of Gram-positive and Gram-negative bacteria. Int J Syst Evol Microbiol 52, 1477-1484.

Muir, R. E. \& Tan, M.-W. (2007). Leucobacter chromiireducens subsp. solipictus subsp. nov., a pigmented bacterium isolated from the nematode Caenorhabditis elegans, and emended description of $L$. chromiireducens. Int J Syst Evol Microbiol 57, 2770-2776.

Naumova, I. B., Kuznetsov, V. D., Kudrina, K. S. \& Bezzubenkova, A. P. (1980). The occurrence of teichoic acids in Streptomyces. Arch Microbiol 126, 71-75.

Naumova, I. B., Shashkov, A. S., Tul'skaya, E. M., Streshinskaya, G. M., Kozlova, Yu. I., Potekhina, N. V., Evtushenko, L. I. \& Stackebrandt, E. (2001). Cell wall teichoic acids: structural diversity, species-specificity in the genus Nocardiopsis and chemotaxonomic perspective. FEMS Microbiol Rev 25, 269-284.

Oberreuter, H., Seiler, H. \& Scherer, S. (2002). Identification of coryneform bacteria and related taxa by Fourier-transform infrared (FT-IR) spectroscopy. Int J Syst Evol Microbiol 52, 91-100.

Oda, M. (1935). Bacteriological studies on water used for brewing saké (part 6). Bacteriological studies on "miyamizu" (8) and (9). Micrococcus and Actinomyces isolated from "miyamizu". Jozogaku Zashi 13, 1202-1228.

Onishi, M. (1949). Studies on the actinomyces isolated from the deeper layer of carious dentine. J Dent Res 6, 273-282.

Onishi, H. \& Kamekura, M. (1972). Micrococcus halobius sp. n. Int J Syst Bacteriol 22, 233-236.

Orla-Jensen, S. (1919). The Lactic Acid Bacteria. Copenhagen: Host and Son.

Ortiz-Martinez, A., Gonzalez, J. M., Evtushenko, L. I., Jurado, V., Laiz, L. \& Groth, I. (2004). Reclassification of Agromyces fucosus subsp. hippuratus as Agromyces hippuratus sp. nov., comb. nov. and emended description of Agromyces fucosus. Int J Syst Evol Microbiol 54, 1553-1556.

Park, Y. H., Suzuki, K., Yim, D. G., Lee, K. C., Kim, E., Yoon, J., Kim, S., Kho, Y. H., Goodfellow, M. \& Komagata, K. (1993). Suprageneric classification of peptidoglycan group $\mathrm{B}$ actinomycetes by nucleotide sequencing of 5S ribosomal RNA. Antonie van Leeuwenhoek 64, 307-313.

Potekhina, N. V., Shashkov, A. S., Evtushenko, L. I., Senchenkova, S. N. \& Naumova, I. B. (2003a). A mannitol teichoic acid containing rhamnose and pyruvic acid acetal from the cell wall of Brevibacterium permense VKM Ac-2280. Carbohydr Res 338, 2745-2749. 
Potekhina, N. V., Shashkov, A. S., Evtushenko, L. I., Gavrish, E. Yu., Senchenkova, S. N., Stomakin, A. A., Usov, A. I., Naumova, I. B. \& Stackebrandt, E. (2003b). A novel mannitol teichoic acid with side phosphate groups of Brevibacterium sp. VKM Ac-2118. Eur J Biochem 270, 4420-4425.

Potekhina, N. V., Evtushenko, L. I., Senchenkova, S. N., Shashkov, A. S. \& Naumova, I. B. (2004). Structures of cell wall teichoic acids of Brevibacterium iodinum VKM Ac-2106. Biochemistry (Mosc) 69, 13531359.

Potekhina, N. V., Evtushenko, L. I., Senchenkova, S. N. \& Shashkov, A. S. (2007). A new polymer of 8,9-Di-O-Glucosylated 2-keto-3deoxy-D-glycero-D-galacto-nonulosonic acid from a cell wall of Brevibacterium casei VKM Ac- $2114^{\mathrm{T}}$. Russ J Bioorganic Chem 33, 66-72.

Poyart, C., Quesne, G., Boumaila, C. \& Trieu-Cuot, P. (2001). Rapid and accurate species-level identification of coagulase-negative staphylococci by using the $\operatorname{sodA}$ gene as a target. J Clin Microbiol 39, 4296-4301.

Prauser, H., Lechevalier, M. P. \& Lechevalier, H. (1970). Description of Oerskovia gen. n. to harbor Ørskov's motile nocardia. Appl Microbiol 19, 534.

Prauser, H., Schumann, P., Rainey, F. A., Kroppenstedt, R. M. \& Stackebrandt, E. (1997). Terracoccus luteus gen. nov., sp. nov., an LLdiaminopimelic acid-containing coccoid actinomycete from soil. Int Syst Bacteriol 47, 1218-1224.

Prévot, S. (1961). Traité de bactériologie systématique. Dunod Paris.

Pribram, E. (1929). A contribution to the classification of microorganisms. J Bacteriol 18, 361-394.

Pukall, R. (2006). DNA fingerprinting techniques applied to the identification, taxonomy and community analysis of Prokaryotes. In Molecular Identification, Systematics and Population Structure of Prokaryotes, pp. 52-82. Edited by E. Stackebrandt. Berlin, Heidelberg, New York: Springer Verlag.

Pukall, R., Schumann, P., Schütte, C., Gols, R. \& Dicke, M. (2006). Acaricomes phytoseiuli gen. nov., sp. nov., isolated from the predatory mite Phytoseiulus persimilis. Int J Syst Evol Microbiol 56, 465-469.

Qiu, F., Huang, Y., Sun, L., Zhang, X., Liu, Z. \& Song, W. (2007). Leifsonia ginsengi sp. nov., isolated from ginseng root. Int J Syst Evol Microbiol 57, 405-408.

Reddy, G. S. N., Prakash, J. S. S., Srinvas, R., Matsumoto, G. I. \& Shivaj, S. (2003). Leifsonia rubra sp. nov. and Leifsonia aurea sp. nov., psychrophiles from a pond in Antarctica. Int J Syst Evol Microbiol 53, 977-984.

Richert, K., Brambilla, E. \& Stackebrandt, E. (2005). Development of PCR primers specific for the amplification and direct sequencing of gyrB genes from microbacteria, order Actinomycetales. J Microbiol Methods 60, 115-123.

Rivas, R., Sanchez, M., Trujillo, M. E., Zurdo-Pineiro, J. L., Mateos, P. F., Martinez-Molina, E. \& Velazquez, E. (2003). Xylanimonas cellulosilytica gen. nov., sp. nov., a xylanolytic bacterium isolated from a decayed tree (Ulmus nigra). Int J Syst Evol Microbiol 53, 99-103.

Rivas, R., Trujillo, M. E., Schumann, P., Kroppenstedt, R. M., Sanchez, M., Mateos, P. F., Martinez-Molina, E. \& Velazquez, E. (2004). Xylanibacterium ulmi gen. nov., sp. nov., a novel xylanolytic member of the family Promicromonosporaceae. Int $J$ Syst Evol Microbiol 54, 557-561.

Rocourt, J., Wehmeyer, U. \& Stackebrandt, E. (1987). Transfer of Listeria denitrificans into a new genus Jonesia gen. nov. as Jonesia denitrificans comb. nov. Int J Syst Bacteriol 37, 266-270.

Ryu, E. (1938). On the Gram-differentiation of bacteria by the simplest method. J Jpn Soc Vet Sci 17, 58-63.
Saddler, G. S., Tavecchia, P., Lociuro, S., Zanol, M., Colombo, L. \& Selva, E. (1991). Analysis of madurose and other actinomycete whole cell sugars by gas chromatography. J Microbiol Methods 14, 185-191.

Sanders, J. E. \& Fryer, J. L. (1980). Renibacterium salmoninarum gen. nov., sp. nov., the causative agent of bacterial kidney disease in salmonid fishes. Int J Syst Bacteriol 30, 496-502.

Sasaki, J., Chijimatsu, M. \& Suzuki, K. (1998). Taxonomic significance of 2,4-diaminobutyric acid isomers in the cell wall peptidoglycan of actinomycetes and reclassification of Clavibacter toxicus as Rathayibacter toxicus comb. nov. Int J Syst Bacteriol 48, 403410.

Scherer, P. \& Kneifel, H. (1983). Distribution of polyamines in methanogenic bacteria. J Bacteriol 154, 1315-1322.

Schippers-Lammertse, A. F., Muijsers, A. O. \& Klatser-Oedekerk, K. B. (1963). Arthrobacter polychromogenes, its pigments and a bacteriophage of this species. Antonie van Leeuwenhoek 29, 1-15.

Schleifer, K. H. (1985). Analysis of the chemical composition and primary structure of murein. Methods Microbiol 18, 123-156.

Schleifer, K. H. \& Kandler, O. (1972). Peptidoglycan types of bacterial cell walls and their taxonomic implications. Bacteriol Rev 36, 407-477.

Schroeter, J. (1872). Über einige durch Bakterien gebildete Pigmente. Beitr Biol Pflanz 1, 109-126 (in German).

Schubert, K., Ludwig, W., Springer, N., Kroppenstedt, R., Accolas, J. \& Fiedler, F. (1996). Two coryneform bacteria isolated from the surface of French Gruyere and Beaufort cheeses are new species of the genus Brachybacterium: Brachybacterium alimentarium sp. nov. and Brachybacterium tyrofermentans sp. nov. Int J Syst Bacteriol 46, 81-87.

Schumann, P. \& Prauser, H. (1995). Minimal standards for taxa related to Arthrobacter and Microbacterium. In Proceedings of the Ninth International Symposium on the Biology of Actinomycetes. Part II. Edited by V. G. Debabov, Y. V. Dudnik \& V. N. Danilenko. New York: Allerton Press Inc.

Schumann, P., Weiss, N. \& Stackebrandt, E. (2001). Reclassification of Cellulomonas cellulans (Stackebrandt and Keddie 1986) as Cellulosimicrobium cellulans gen. nov., comb. nov. Int J Syst Evol Microbiol 51, 1007-1010.

Schumann, P., Behrendt, U., Ulrich, A. \& Suzuki, K. (2003). Reclassification of Subtercola pratensis Behrendt et al. 2002 as Agreia pratensis comb. nov. Int J Syst Evol Microbiol 53, 2041-2044.

Shashkov, A. S., Potekhina, N. V., Evtushenko, L. I. \& Naumova, I. B. (2004). Cell wall teichoic acids of two Brevibacterium strains. Biochemistry (Mosc) 69, 658-664.

Sheridan, P. P., Loveland-Curtze, J., Miteva, V. I. \& Brenchley, J. E. (2003). Rhodoglobus vestalii gen. nov., sp. nov., a novel psychrophilic organism isolated from an Antarctic Dry Valley lake. Int J Syst Evol Microbiol 53, 985-994.

Shirling, E. B. \& Gottlieb, D. (1966). Methods for the characterization of Streptomycetes species. Int J Syst Bacteriol 16, 313-340.

Skerman, V. B. D., McGowan, V. \& Sneath, P. H. A. (editors) (1980). Approved lists of bacterial names. Int J Syst Bacteriol 30, 225-420.

Smibert, R. M. \& Krieg, N. R. (1994). Phenotypic characterization. In Methods for General and Molecular Bacteriology, pp. 607-654. Edited by P. Gerhart, R. G. E. Murray, W. A. Wood \& N. R. Krieg. Washington, DC: American Society for Microbiology.

Smith, E. F. (1910). A new tomato disease of economic importance. Science 31, 794-796.

Smith, E. F. (1913). A new type of bacterial disease. Science 38, 926.

Sneath, P. H. A., Mair, N. A., Sharpe, M. E. \& Holt, J. G. (1986). Bergey's Manual of Systematic Bacteriology, vol. 2. Baltimore, MD: Williams and Wilkins. 
Sorokin, D. Yu. (2005). Is there a limit for high-pH life? Int J Syst Evol Microbiol 55, 1405-1406.

Stackebrandt, E. (2002). From species definition to species concept: population genetics is going to influence the systematics of Prokaryotes. WFCC Newsl 35, http://www.wfcc.info/NEWSLETTER/ newsletter35/a1.pdf

Stackebrandt, E. \& Goebel, B. M. (1994). Taxonomic note: a place for DNA-DNA reassociation and $16 \mathrm{~S}$ rRNA sequence analysis in the present species definition in bacteriology. Int J Syst Bacteriol 44, 846-849.

Stackebrandt, E. \& Prauser, H. (1991). The family Cellulomonadaceae. In The Prokaryotes, pp. 1323-1345. Edited by A. Balows, H. G. Trüper, M. Dworkin, W. Harder \& K.-H. Schleifer. New York: Springer Verlag.

Stackebrandt, E. \& Schumann, P. (2000). Description of Bogoriellaceae fam. nov., Dermacoccaceae fam. nov., Rarobacteraceae fam. nov. and Sanguibacteraceae fam. nov. and emendation of some families of the suborder Micrococcineae. Int J Syst Evol Microbiol 50, 1279-1285.

Stackebrandt, E. \& Schumann, P. (2004). Reclassification of Promicromonospora pachnodae Cazemier et al. 2004 as Xylanimicrobium pachnodae gen. nov., comb. nov. Int J Syst Evol Microbiol 54, 1383-1386.

Stackebrandt, E. \& Schumann, P. (2006). Introduction to the taxonomy of actinobacteria. In The Prokaryotes. A Handbook on the Biology of Bacteria, 3rd edn, vol. 3, pp. 297-321. Edited by M. Dworkin, S. Falkow, E. Rosenberg, K. H. Schleifer \& E. Stackebrandt. New York: Springer-Verlag.

Stackebrandt, E., Koch, C., Gvozdiak, O. \& Schumann, P. (1995). Taxonomic dissection of the genus Micrococcus: Kocuria gen. nov., Nesterenkonia gen. nov., Kytococcus gen. nov., Dermacoccus gen. nov., and Micrococcus Cohn 1872 gen. emend. Int J Syst Bacteriol 45, 682-692.

Stackebrandt, E., Rainey, F. \& Ward-Rainey, N. (1997). Proposal for a new hierarchic classification system, Actinobacteria classis nov. Int $J$ Syst Bacteriol 47, 479-491.

Stackebrandt, E., Breymann, S., Steiner, U., Prauser, H. N. W. \& Schumann, P. (2002a). Re-evaluation of the status of the genus Oerskovia, reclassification of Promicromonospora enterophila (Jáger et al. 1983) as Oerskovia enterophila comb. nov. and description of Oerskovia jenensis sp. nov. and Oerskovia paurometabola sp. nov. Int J Syst Evol Microbiol 52, 1105-1111.

Stackebrandt, E., Frederiksen, W., Garrity, G. M., Grimont, P., Kämpfer, P., Maiden, M., Nesme, X., Rossello-Mora, R., Swings, J. \& other authors (2002b). Report of the ad hoc committee for the reevaluation of the species definition in bacteriology. Int J Syst Evol Microbiol 52, 1043-1047.

Stackebrandt, E., Schumann, P. \& Cui, X.-L. (2004). Reclassification of Cellulosimicrobium variabile Bakalidou et al. 2002 as Isoptericola variabilis gen. nov., comb. nov. Int J Syst Evol Microbiol 54, 685-688.

Stackebrandt, E., Päuker, O. \& Erhard, M. (2005). Grouping myxococci (Corallococcus) strains by matrix-assisted laser desorption ionization time-of-flight (MALDI TOF) mass spectrometry: Comparison with gene sequence phylogenies. Curr Microbiol 50, 71-77.

Starr, M. P. (1958). The blue pigment of Corynebacterium indisiosum. Arch Mikrobiol 30, 325-334.

Starr, M. P. \& Saperstein, S. (1953). Thiamine and the carotenoid pigments of Corynebacterium poinsettiae. Arch Biochem Biophys 43, 157-168.

Streshinskaya, G. M., Shashkov, A. S., Usov, A. I., Evtushenko, L. I. \& Naumova, I. B. (2002). Cell wall teichoic acids of actinomycetes of three genera of the order actinomycetales. Biochemistry (Mosc) 67, $778-785$.
Suzuki, K. \& Komagata, K. (1983). Taxonomic significance of cellular fatty acid composition in some coryneform bacteria. Int $J$ Syst Bacteriol 33, 188-200.

Suzuki, K., Sasaki, J., Uramoto, M., Nakase, T. \& Komagata, K. (1997). Cryobacterium psychrophilum gen. nov., sp. nov., nom. rev., comb. nov., an obligately psychrophilic actinomycete to accommodate "Curtobacterium psychrophilum" Inoue and Komagata 1976. Int J Syst Bacteriol 47, 474-478.

Takeuchi, M. \& Hatano, K. (1998). Union of the genera Microbacterium Orla-Jensen and Aureobacterium Collins et al. in a redefined genus Microbacterium. Int J Syst Bacteriol 48, 739-747.

Takeuchi, M. \& Yokota, A. (1989). Cell wall polysaccharides in coryneform bacteria. J Gen Appl Microbiol 35, 233-253.

Takeuchi, M., Weiss, N., Schumann, P. \& Yokota, A. (1996). Leucobacter komagatae gen. nov., sp. nov., a new aerobic grampositive, nonsporulating rod with 2,4-diaminobutyric acid in the cell wall. Int J Syst Bacteriol 46, 967-971.

Tamaoka, J. \& Komagata, K. (1984). Determination of DNA base composition by reversed-phase high-performance liquid chromatography. FEMS Microbiol Lett 25, 125-128.

Tanaka, N., Uchimura, T. \& Komagata, K. (2001). The formation and structures of cystites of Arthrobacter ureafaciens NRIC $0157^{\mathrm{T}}$ induced by antibiotics. J Gen Appl Microbiol 47, 85-97.

Tiago, I., Pires, C., Mendes, V., Morais, P. V., da Costa, M. \& Verissimo, A. (2005). Microcella putealis gen. nov., sp. nov., a grampositive alkaliphilic bacterium isolated from a nonsaline alkaline groundwater. Syst Appl Microbiol 28, 479-487.

Tiago, I., Morais, P. V., da Costa, M. S. \& Verissimo, A. (2006). Microcella alkaliphila sp. nov., a novel member of the family Microbacteriaceae isolated from a non-saline alkaline groundwater, and emended description of the genus Microcella. Int J Syst Evol Microbiol 56, 2313-2316.

Tindall, B. J. (1990). Lipid composition of Halobacterium lacusprofundi. FEMS Microbiol Lett 66, 199-202.

Tindall, B. J. (1999). Proposal to change the Rule governing the designation of type strains deposited under culture collection numbers allocated for patent purposes. Int J Syst Bacteriol 49, 1317-1319.

Tindall, B. J. (2008). Confirmation of deposit, but confirmation of what? Int J Syst Evol Microbiol 58, 1785-1787.

Tindall, B. J. \& Garrity, G. M. (2008). Proposals to clarify how type strains are deposited and made available to the scientific community for the purpose of systematic research. Int J Syst Evol Microbiol 58, 1987-1990.

Tindall, B. J., Kämpfer, P., Euzéby, J. P. \& Oren, A. (2006). Valid publication of names of prokaryotes according to the rules of nomenclature: past history and current practice. Int J Syst Evol Microbiol 56, 2715-2720.

Trutko, S. M., Evtushenko, L. I., Gavrish, E. Yu., Dorofeeva, L. V., Shlyapnikov, M. G. \& Akimenko, V. K. (2003). Terminal oxidases in different genera of the family Microbacteriaceae. Mikrobiologiia 72, 301-307.

Trutko, S. M., Dorofeeva, L. V., Evtushenko, L. I., Ostrovskii, D. N., Hintz, M., Wiesner, J., Jomaa, H., Baskunov, B. P. \& Akimenko, V. K. (2005). Isoprenoid pigments in representatives of the family Microbacteriaceae. Microbiology (English translation of Mikrobiologiia) 74, 284-289.

Tsukamoto, T., Takeuchi, M., Shida, O., Murata, H. \& Shirata, A. (2001). Proposal of Mycetocola gen. nov. in the family Microbacteriaceae and three new species, Mycetocola saprophilus sp. nov., Mycetocola tolaasinivorans sp. nov. and Mycetocola lacteus sp. 
nov., isolated from cultivated mushroom, Pleurotus ostreatus. Int J Syst Evol Microbiol 51, 937-944.

Turner, J. M. \& Messenger, A. J. (1986). Occurrence, biochemistry and physiology of phenazine pigment production. Adv Microb Physiol 27, 211-275.

Uchida, K. \& Aida, K. (1984). An improved method for the glycolate test for simple identification of the acyl type of bacterial cell walls. J Gen Appl Microbiol 30, 131-134.

Uchida, K., Kudo, T., Suzuki, K. \& Nakase, T. (1999). A new rapid method of glycolate test by diethyl ether extraction, which is applicable to a small amount of bacterial cells of less than one milligram. J Gen Appl Microbiol 45, 49-56.

Unden, G. (1999). Aerobic respiration and regulation of aerobic/ anaerobic metabolism. In Biology of the Prokaryotes, pp. 261-277. Edited by J. W. Lengeler, G. Drews \& H. G. Schlegel. Stuttgart: Georg Tieme Verlag.

Vandamme, P., Pot, B., Gillis, M., De Vos, P., Kersters, K. \& Swings, J. (1996). Polyphasic taxonomy, a consensus approach to bacterial systematics. Microbiol Rev 60, 407-438.

Van Saceghem, R. (1915). Dermatose contagieuse (impetigo contagieux). Bull Soc Pathol Exot 8, 354-359.

Vargha, M., Takats, Z., Konopka, A. \& Nakatsu, C. H. (2006). Optimization of MALDI-TOF MS for strain level differentiation of Arthrobacter isolates. J Microbiol Methods 66, 399-409.

Vaz-Moreira, I., Nobre, M. F., Ferreira, A. C., Schumann, P., Nunes, O. C. \& Manaia, C. M. (2008). Humibacter albus gen. nov., sp. nov., isolated from sewage sludge compost. Int J Syst Evol Microbiol 58, 1014-1018.

Vidaver, A. K. \& Davis, M. J. (1988). Coryneform plant pathogens. In Laboratory Guide for Identification of Plant Pathogenic Bacteria, 2nd edn, pp. 104-113. Edited by N. W. Schaad. St. Paul, MN: APS press.

von Wintzingerode, F., Göbel, U. B., Siddiqui, R. A., Rosick, U., Schumann, P., Frühling, A., Rohde, M., Pukall, R. \& Stackebrandt, E. (2001). Salana multivorans gen. nov., sp. nov., a novel actinobacterium isolated from an anaerobic bioreactor and capable of selenate reduction. Int J Syst Evol Microbiol 51, 1653-1661.

Ward, N. L., Rainey, F. A., Hedlund, B. P., Staley, J. T., Ludwig, W. \& Stackebrandt, E. (2000). Comparative phylogenetic analyses of members of the order Planctomycetales and the division Verrucomicrobia: 23S rRNA gene sequence analysis supports the 16S rRNA gene sequence-derived phylogeny. Int J Syst Evol Microbiol 50, 1965-1972.

Weeks, O. B. (1981). Preliminary studies of the pigments of Flavobacterium breve NCTC 11099 and Flavobacterium odoratum NCTC 11036. In The Flavobacterium-Cytophaga Group, pp. 108-114. Edited by H. Reichenbach \& O. B. Weeks. Weinheim: Gesellschaft fur Biotechnologische Forschung.

Whiley, R. A. \& Kilian, M. (2003). International Committee on Systematics of Prokaryotes Subcommittee on the taxonomy of staphylococci and streptococci: Minutes of the closed meeting, 31 July 2002, Paris, France. Int J Syst Evol Microbiol 53, 915-917.

Wiegel, J. (1981). Distinction between the Gram reaction and the Gram type of bacteria. Int J Syst Bacteriol 31, 88.

Wieser, M., Denner, E. B., Kämpfer, P., Schumann, P., Tindall, B., Steiner, U., Vybiral, D., Lubitz, W., Maszenan, A. M. \& other authors (2002). Emended descriptions of the genus Micrococcus, Micrococcus luteus (Cohn 1872) and Micrococcus lylae (Kloos et al. 1974). Int J Syst Evol Microbiol 52, 629-637.
Wolff, M. (1910). Über eine neue Krankheit der Raupe von Bupalus piniarius L. Mitt K Wilh Landw Bromberg 3, 69-92 (in German).

Yamada, K. \& Komagata, K. (1972). Taxonomic studies on coryneform bacteria. V. Classification of coryneform bacteria. J Gen Appl Microbiol 18, 417-431.

Yamamoto, N., Sato, S., Saito, K., Hasuo, T., Tadenuma, M., Suzuki, K., Tamaoka, J. \& Komagata, K. (1988). Rarobacter faecitabidus gen. nov., sp. nov., a yeast-lysing coryneform bacterium. Int J Syst Bacteriol 38, 7-11.

Yi, H., Schumann, P., Sohn, K. \& Chun, J. (2004). Serinicoccus marinus gen. nov., sp. nov., a novel actinomycete with L-ornithine and L-serine in the peptidoglycan. Int J Syst Evol Microbiol 54, 1585-1589.

Yi, H., Schumann, P. \& Chun, J. (2007). Demequina aestuarii gen. nov., sp. nov., a novel actinomycete of the suborder Micrococcineae, and reclassification of Cellulomonas fermentans Bagnara et al. 1985 as Actinotalea fermentans gen. nov., comb. nov. Int J Syst Evol Microbiol 57, 151-156.

Yoon, J. H., Kang, S. J., Schumann, P. \& Oh, T. K. (2006). Yonghaparkia alkaliphila gen. nov., sp. nov., a novel member of the family Microbacteriaceae isolated from an alkaline soil. Int J Syst Evol Microbiol 56, 2415-2420.

Zgurskaya, H. I., Evtushenko, L. I., Akimov, V. N., Voyevoda, H. V., Dobrovolskaya, T. G., Lysak, L. V. \& Kalakoutskii, L. V. (1992). Emended description of the genus Agromyces and description of Agromyces cerinus subsp. cerinus sp. nov., subsp. nov., Agromyces cerinus subsp. nitratus sp. nov., subsp. nov., Agromyces fucosus subsp. fucosus sp. nov., subsp. nov., Agromyces fucosus subsp. hippuratus sp. nov., subsp. nov. Int J Syst Bacteriol 42, 635-641.

Zgurskaya, H. I., Evtushenko, L. I., Akimov, V. N. \& Kalakoutskii, L. V. (1993). Rathayibacter gen. nov., including the species Rathayibacter rathayi comb. nov., Rathayibacter tritici comb. nov., Rathayibacter iranicus comb. nov., and six strains from annual grasses. Int J Syst Bacteriol 43, 143-149.

Zhang, Y. Q., Schumann, P., Yu, L. Y., Liu, H. Y., Xu, L. H., Stackebrandt, E., Jiang, C. L. \& Li, W. J. (2007a). Zhihengliuella halotolerans gen. nov., sp. nov., a novel member of the family Micrococcaceae. Int J Syst Evol Microbiol 57, 1018-1023.

Zhang, L., Xu, Z. \& Patel, B. K. C. (2007b). Frondicola australicus gen. nov., sp. nov., isolated from decaying leaf litter from a pine forest. Int J Syst Evol Microbiol 57, 1177-1182.

Zhi, X.-Y., Li, W.-J. \& Stackebrandt, E. (2009). An update of the structure and 16S rRNA gene sequence-based definition of higher ranks of the class Actinobacteria, with the proposal of two new suborders and four new families and emended descriptions of the existing higher taxa. Int J Syst Evol Microbiol 59, 589-608.

Ziemke, F., Höfle, M. G., Lalucat, J. \& Rosselló-Mora, R. (1998). Reclassification of Shewanella putrefaciens Owen's genomic group II as Shewanella baltica sp. nov. Int J Syst Bacteriol 48, 179-186.

Zlamala, C., Schumann, P., Kämpfer, P., Rossello-Mora, R., Lubitz, W. \& Busse, H. J. (2002a). Agrococcus baldri sp. nov., isolated from the air in the 'Virgilkapelle' in Vienna. Int J Syst Evol Microbiol 52, 1211-1216.

Zlamala, C., Schumann, P., Kämpfer, P., Valens, M., Rossello-Mora, R., Lubitz, W. \& Busse, H. J. (2002b). Microbacterium aerolatum sp. nov., isolated from the air in the 'Virgilkapelle' in Vienna. Int J Syst Evol Microbiol 52, 1229-1234.

ZoBell, C. E. \& Upham, C. (1944). A list of marine bacteria including descriptions of sixty new species. Bull Scripps Inst Oceanogr Univ Calif Tech Ser 5, 239-292. 